\title{
Iancu v. Brunetti's Impact on First Amendment Law: Viewpoint Discrimination, Modes of Offensive Expression, Proportionality and Profanity
}

\author{
Clay Calvert*
}

\begin{abstract}
This article analyzes and contextualizes multiple effects on First Amendment jurisprudence of the United States Supreme Court's 2019 trademark ruling in Iancu $v$. Brunetti. It explores what the five opinions in the case reveal regarding the justices' divergent views on both offensive speech and standards of scrutiny. The six-justice Brunetti majority struck down part of the federal Lanham Act that allowed the United States Patent and Trademark Office ("PTO") to deny registration to marks it deemed immoral or scandalous. Yet several justices wanted to permit the PTO to reject registration for vulgar or profane marks that offend based not on the ideas or views conveyed, but rather because of the manner and mode of expression. Furthermore, the majority specified it was silent about such a censorial mode-ofexpression possibility. Beyond examining what this portends for Congress in drafting a new statute, the article also considers: (1) Brunetti's implications for the doctrine against viewpoint-based discrimination; (2) Justice Stephen Breyer's continued assault on the Court's traditional categorical approach to First Amendment cases; and (3) how Brunetti indirectly breathes life into the Federal Communications Commission's quiescent regulation of profanity on the broadcast airwaves. Ultimately, while the Court under Chief Justice John Roberts's leadership has protected offensive speech in cases such as Snyder v. Phelps and United States v. Stevens, the quintet of opinions in Brunetti reveals that this benevolence has limits, especially when government protection confers benefits upon such expression.
\end{abstract}

* Professor \& Brechner Eminent Scholar in Mass Communication and Director of the Marion B. Brechner First Amendment Project at the University of Florida in Gainesville, Fla. B.A., 1987, Communication, Stanford University; J.D. (Order of the Coif), 1991, McGeorge School of Law, University of the Pacific; Ph.D., 1996, Communication, Stanford University.

(C) 2019 Clay Calvert. This is an open access article distributed under the terms of the Creative Commons Attribution - NonCommercial - NoDerivatives License, which permits noncommercial use, distribution, and reproduction, provided the original author and source are credited. 
TABLE OF CONTENTS

Introduction.

I. Offensive Speech and Modes of Expression: Exposing Cracks in the Wall of First Amendment Protection........................................ 42

A. Protecting Offensive Expression.............................................. 43

B. Viewpoint Discrimination is Forbidden ................................. 48

C. Chipping Away at the Wall of Protection for Offensive Speech: The Justices' Concerns About Registering Offensive Marks and How They Might Draft a Better Statute Focusing on the Mode of Expression ......................... 50

1. Worries About the Future of Trademark Registration........ 50

2. Legal Hooks Upon Which to Hang the PTO's Regulation of Offensive Marks

3. How the Justices Would Craft a Ban on Offensive Marks

a. Justice Kagan and the Majority Opinion ..................... 55

b. Chief Justice Roberts's Opinion.................................. 55

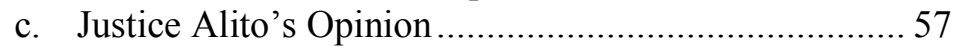

d. Justice Sotomayor's Opinion ....................................... 58

e. Justice Breyer's Opinion ......................................... 61

II. Of Proportionality and Scrutiny: A Closer Look at Brunetti ............... 64

A. Justice Breyer: Doctrinal Categories, Rules of Thumb and

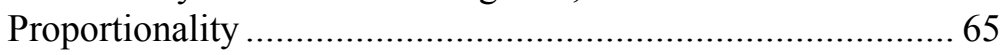

B. Justice Sotomayor on Scrutiny in an Offensive-Mode-ofExpression Analysis in Trademark Law....

III. Connecting the Agency Dots Between the PTO and the FCC: Will

Brunetti Embolden the FCC to Regulate Profanity? ...................... 79

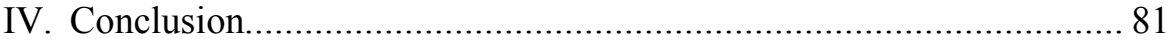




\section{INTRODUCTION}

In June 2019, the United States Supreme Court in Iancu v. Brunetti held that part of a federal statute vesting the United States Patent and Trademark Office ("PTO") with authority to refuse registration for marks it deemed immoral or scandalous violated the First Amendment guarantee of free speech. ${ }^{1}$ Writing for a six-justice majority, Elena Kagan concluded that both facets of this provision-its "immoral" and "scandalous" components-were unconstitutional because they let the PTO impermissibly discriminate against viewpoints. ${ }^{2}$

Specifically, Justice Kagan explained that the PTO had used the statute to rebuff registration for "marks communicating 'immoral' or 'scandalous' views about... drug use, religion, and terrorism," while simultaneously approving "registration of marks expressing more accepted views on the same topics." In brief, the PTO took sides. It discriminated against some ideas and opinions under the statute, violating what Kagan called "a core postulate of free speech law." The Court's ruling now affords Erik Brunetti the right to register "FUCT"-a mark that both a PTO examining attorney and the agency's Trademark Trial and Appeal Board ("TTAB") declared immoral and scandalous - for a line of clothing. ${ }^{5}$

The outcome in Brunetti was unsurprising for two key reasons. First, the Court just two years before, in Matal v. Tam, had struck down another part of the same law that allowed the PTO to block registration for disparaging marks. ${ }^{6}$ That case pivoted on Simon Tam's efforts to register "The Slants" as the mark for his band comprising Asian Americans. ${ }^{7}$ While Tam, the group's frontman, sought to register the mark to reclaim a derogatory term for Asians, ${ }^{8}$ the PTO rejected his application, finding it

1. Iancu v. Brunetti, 139 S. Ct. 2294 (2019). The statute at issue was 15 U.S.C. § 1052(a), which in relevant part allowed the PTO to deny registration if a mark "[c]onsists of or comprises immoral, deceptive, or scandalous matter.” 15 U.S.C. § 1052(a) (2018) (emphasis added).

The First Amendment to the U.S. Constitution provides, in relevant part, that "Congress shall make no law ... abridging the freedom of speech, or of the press." U.S. CONST. amend. I. The Free Speech and Free Press Clauses were incorporated ninety-five years ago through the Fourteenth Amendment Due Process Clause as fundamental liberties to apply to state and local government entities and officials. See Gitlow v. New York, 268 U.S. 652, 666 (1925) (finding "that freedom of speech and of the press - which are protected by the First Amendment from abridgment by Congress - are among the fundamental personal rights and 'liberties' protected by the due process clause of the Fourteenth Amendment from impairment by the States").

2. Brunetti, 139 S. Ct. at 2299-2300.

3. Id. at 2300 .

4. Id. at 2299

5. Id. at 2297-98. Among other things, the TTAB found "FUCT" was highly offensive and vulgar, adding that Erik Brunetti, an artist and entrepreneur who founded a clothing line that uses the trademark FUCT, used it on his website and in close proximity to imagery in a misogynistic and depraved manner. $I d$.

6. Matal v. Tam, 137 S. Ct. 1744 (2017); see 15 U.S.C. § 1052(a) (2018) (allowing the PTO to deny registration for marks that "may disparage or falsely suggest a connection with persons, living or dead, institutions, beliefs, or national symbols, or bring them into contempt, or disrepute" (emphasis added)).

7. Tam, 137 S. Ct. at 1751 .

8. See id. (observing that "the band members believe that by taking that slur as the name of their group, they will help to 'reclaim' the term and drain its denigrating force"). 
offensive and disparaging to a substantial composite of members of that ethnicity. ${ }^{9}$ Handing Simon Tam a victory, all eight justices who participated in the case concluded that the disparagement clause was fatally viewpoint-based, although they split neatly into two blocs of four in expressing that position. ${ }^{10}$

Additionally, Tam buttressed the principle that the First Amendment generally protects offensive speech. As Justice Samuel Alito wrote in delivering the Court's opinion, the disparagement clause "offends a bedrock First Amendment principle: Speech may not be banned on the ground that it expresses ideas that offend."11 Alito added that the notion that "[t]he Government has an interest in preventing speech expressing ideas that offend ... strikes at the heart of the First Amendment."12

Second, the result in Brunetti was largely predictable because the Court, under Chief Justice John Roberts's leadership in cases beyond Tam, generally has been favorable to protecting a wide swath of expression that some, for various reasons, might consider offensive. For example, in Snyder v. Phelps, the Court in 2011 shielded from tort liability members of the Westboro Baptist Church who hoisted signs emblazoned with messages such as "God Hates Fags," "Thank God for Dead Soldiers," and "Pope in Hell" near a funeral for a U.S. soldier killed on duty in Iraq. ${ }^{13}$ That same year, the Roberts Court also vitiated a law restricting minors' access to graphically violent video games. ${ }^{14}$ Furthermore, with Roberts at the helm, the Court

\section{Id. at 1754 .}

10. Writing a portion of the opinion joined by Chief Justice John Roberts and Justices Clarence Thomas and Stephen Breyer, Justice Samuel Alito reasoned that "[o]ur cases use the term 'viewpoint' discrimination in a broad sense . . . and in that sense, the disparagement clause discriminates on the bases of "viewpoint." Tam, $137 \mathrm{~S}$. Ct. at 1673. Alito added that the disparagement clause "denies registration to any mark that is offensive to a substantial percentage of the members of any group" and that, in turn, "[g]iving offense is a viewpoint." Id.

Engaging in a much more extensive discussion of the rule against viewpoint-based discrimination, Justice Anthony Kennedy-joined by Justices Ruth Bader Ginsburg, Sonia Sotomayor, and Elena Kagan — explained that under the disparagement clause, "an applicant may register a positive or benign mark but not a derogatory one. The law thus reflects the Government's disapproval of a subset of messages it finds offensive. This is the essence of viewpoint discrimination." Id. at 1766 (Kennedy, J., concurring). Kennedy elaborated that "the test for viewpoint discrimination is whether-within the relevant subject category - the government has singled out a subset of messages for disfavor based on the views expressed." Id.

See generally Clay Calvert, Beyond Trademarks and Offense: Tam and the Justices' Evolution on Free Speech, 2017 CATO SuP. CT. REV. 25, 49-54 (2017) [hereinafter Calvert, Beyond Trademarks] (comparing and contrasting the approaches of Justices Alito and Kennedy in Tam on the issue of viewpoint-based discrimination).

11. Tam, 137 S. Ct. at 1751 .

12. Id. at 1764 .

13. Snyder v. Phelps, 562 U.S. 443, 448 (2011). The seven members of the Westboro Baptist Church who participated in this particular protest, including its then-leader, the Reverend Fred Phelps, stood peacefully for about thirty minutes on public land approximately 1,000 feet away from the church where the funeral was held. Id. at 448-49.

14. Brown v. Entm't Merchs. Ass'n, 564 U.S. 786 (2011). The statute at issue in Brown can reasonably be said to have targeted offensive speech because the violent video games it covered were defined, in key part, as those featuring the "killing, maiming, dismembering, or sexually assaulting [of] an image of a human being" in a way that "appeals to a deviant or morbid interest of minors." Id. at 789. The majority in Brown held that the law failed to survive the strict scrutiny test that typically applies to content-based statutes. Id. at 799-800. 
invalidated a federal statute that targeted images of animal cruelty and, in the process, refused to carve out a new category of unprotected expression for such depictions. ${ }^{15}$ Additionally, the Court in 2012 declared unconstitutional, due to its vastly expansive nature, a federal statute that made it crime to lie about having won a Congressional Medal of Honor. ${ }^{16}$

Although Brunetti's outcome was therefore foreseeable, the totality of the five opinions it spawned demonstrates there are: (1) limits on just how far some justices will go in safeguarding offensive expression, especially when such protection results in government-conferred benefits; (2) significant problems, including definitional ones, with carving out new exceptions for some varieties of offensive expression; and (3) doctrinal disagreements among the justices regarding how such cases should be analyzed. These issues and others are the focus of this Article.

Despite Brunetti's decidedly pro-free speech conclusion and its unmistakable reinforcement of the First Amendment doctrine prohibiting viewpoint-based discrimination of speech, it was anything but a simple repeat or decisional doppelgänger of Tam. In particular, Part I examines how Brunetti exposes fissures in the Court's historically sturdy wall of protection safeguarding offensive speech. Specifically, Part I delves into the willingness of at least four justices - and quite possibly all nine - to allow the PTO to block registration for marks that offend because of their mode of expression rather than because of the underlying viewpoints or ideas they convey. In the process, it also explores how three justices in BrunettiChief Justice Roberts, as well as Justices Stephen Breyer and Sonia Sotomayorwere disposed to giving the word "scandalous" (but not "immoral") a narrowing construction to save it from unconstitutionality.

Part II has two sections. First, it critiques Justice Breyer's now relentless assault

15. United States v. Stevens, 559 U.S. 460 (2010). The U.S. Supreme Court has held that multiple types of expression are not protected by the First Amendment's Free Speech Clause. See United States v. Alvarez, 567 U.S. 709, 717 (2012) (identifying unprotected categories of expression as including incitement to violence, obscenity, defamation, speech integral to criminal conduct, fighting words, child pornography, fraud, true threats, and "speech presenting some grave and imminent threat the government has the power to prevent"); Ashcroft v. Free Speech Coal., 535 U.S. 234, 245-46 (2002) (providing that the First Amendment's "freedom of speech has its limits; it does not embrace certain categories of speech, including defamation, incitement, obscenity, and pornography produced with real children"). The law at issue in Stevens can fairly be said to target offensive speech because the legislative intent behind it was to regulate "crush videos" featuring "the intentional torture and killing of helpless animals, including cats, dogs, monkeys, mice, and hamsters." Stevens, 559 U.S. at 465 . In striking down the statute, the Court rejected the government's position that "the banned depictions of animal cruelty, as a class, are categorically unprotected by the First Amendment." Id. at 468. The Court suggested it would not create new categories of speech unprotected by the First Amendment unless the speech in question has "been historically unprotected." Id. at 472. In delivering the majority opinion, Chief Justice Roberts observed that "we are unaware of any similar tradition excluding depictions of animal cruelty from "the freedom of speech' codified in the First Amendment, and the Government points us to none." Id. at 469.

16. Alvarez, 567 U.S. 709 (2012). In announcing the Court's judgment in a plurality opinion striking down the Stolen Valor Act of 2005, Justice Anthony Kennedy also rejected the twin notions that "all proscriptions of false statements are exempt from exacting First Amendment scrutiny" and that "false speech should be in a general category that is presumptively unprotected." Id. at 720-22. The Stolen Valor Act of 2005 can reasonably be viewed as targeting offensive expression because, as Justice Kennedy opined, "the lie may offend the true holders of the Medal. From one perspective it insults their bravery and high principles when falsehood puts them in the unworthy company of a pretender." Id. at 726. 
on the Court's traditional and categorical tiers-of-scrutiny approach to analyzing free speech cases and his efforts to replace that methodology with his preferred proportionality tack. ${ }^{17}$ Second, it examines Justice Sotomayor's willingness to apply a standard of review less rigorous than strict scrutiny to content-based laws that do not discriminate against viewpoints, at least in contexts where protecting speech is coupled with government-bestowed benefits, as it is with federal trademark registration. ${ }^{18}$ Part II also ponders how an offensive-mode-of-expression rule, as envisioned by Justice Sotomayor, might evade strict scrutiny in contexts beyond Brunetti, even in the face of the Court's 2015 decision in Reed v. Town of Gilbert. ${ }^{19}$

Next, Part III analyzes how Brunetti may provide the key for the Federal Communications Commission to jumpstart its currently dormant enforcement of a statute allowing it to regulate profane language on the broadcast airwaves..$^{20}$ Finally, the Article concludes in Part IV by suggesting that the Court in Brunetti has, in fact, paved the path for Congress to draft a new, more precise statute granting the PTO authority to deny registration to marks that offend because of their shockingly vulgar and profane mode of expression, irrespective of the underlying opinions, ideas, or viewpoints that they convey.

\section{OFFENSIVE SPEECH AND MODES OF EXPRESSION: EXPOSING CRACKS IN THE WALL OF FIRST AMENDMENT PROTECTION}

This Part has three sections. Section A reviews the Supreme Court's generally stout and vigorous protection of offensive speech over approximately the past halfcentury. Section B then illustrates how Brunetti adds teeth to the already robust rule against viewpoint-based discrimination of speech. Section C, however, explores: (a) the willingness of, at a minimum, four justices (both perceived conservatives and liberals, no less) in Brunetti to chip away at the bulwark of First Amendment protection for offensive speech, at least in the trademark-registration context; (b) some of the key reasons propelling that willingness; and (c) the different proposals for restricting the protection. Of particular importance is the possibility of restricting speech that offends not because of the ideas conveyed, but due to the mode and manner in which such ideas are expressed.

17. See Donald L. Beschle, No More Tiers? Proportionality as an Alternative to Multiple Levels of Scrutiny in Individual Rights Cases, 38 PACE L. REV. 384, 419 (2018) (observing that Breyer "has shown some enthusiasm for proportionality analysis in his separate opinions"); Jamal Greene, The Supreme Court 2017 Term: Foreword: Rights as Trumps?, 132 HARV. L. ReV. 28, 55 (2018) ("Proportionality and balancing approaches to rights have long found favor with Justice Breyer.").

18. See Reed v. Town of Gilbert, 135 S. Ct. 2218, 2231 (2015) (observing that strict scrutiny requires the government to prove that a statute "furthers a compelling governmental interest and is narrowly tailored to that end"); United States v. Playboy Entm't Grp., 529 U.S. 803, 813 (2000) (asserting that a content-based speech restriction can withstand judicial review only "if it satisfies strict scrutiny," opining that "[i]f a statute regulates speech based on its content, it must be narrowly tailored to promote a compelling Government interest," and adding that "if a less restrictive alternative would serve the Government's purpose, the legislature must use that alternative").

19. Reed, 135 S. Ct. 2218 (2015).

20. See 18 U.S.C. § 1464 (2018) (making it unlawful to convey "any obscene, indecent, or profane language by means of radio communication"). 


\section{A. Protecting Offensive Expression}

Beyond the decisions noted above protecting offensive speech under Chief Justice Roberts's leadership, ${ }^{21}$ the Court has safeguarded other varieties of offensive expression - stretching from racial to political to sexual — during the past fifty-plus years. For instance, the Court in 1969 in Brandenburg v. Ohio ruled in favor of a Ku Klux Klan leader who was prosecuted for delivering a racist and anti-Semitic speech to his followers on an Ohio farm. ${ }^{22}$ It held that such speech only falls outside the ambit of First Amendment protection if it is "directed to inciting or producing imminent lawless action and is likely to incite or produce such action." 23

Two years later, the Court in Cohen v. California shielded Paul Robert Cohen from criminal punishment after he wore a jacket sporting the message "Fuck the Draft" in a Los Angeles courthouse to protest conscription and the war in Vietnam. ${ }^{24}$ In protecting what it called the "emotive function" of speech, the Court in Cohen acknowledged the definitional difficulties of trying to explicate precisely which types of offensive speech should not be protected, explaining that:

[W]hile the particular four-letter word being litigated here is perhaps more distasteful than most others of its genre, it is nevertheless often true that one man's vulgarity is another's lyric. Indeed, we think it is largely because governmental officials cannot make principled distinctions in this area that the Constitution leaves matters of taste and style so largely to the individual. ${ }^{25}$

Furthermore, the Court in Hustler Magazine v. Falwell in 1988 ruled in favor of a sexually explicit adult magazine's right to make fun of a then-leading conservative religious and political figure by suggesting, in a parody of a Campari liqueur advertisement, that he had sex with his mother in an outhouse, preached while drunk, and was a hypocrite. ${ }^{26}$ In shielding the magazine and its notorious publisher, Larry Flynt, ${ }^{27}$ from tort liability for intentional infliction of emotional distress ("IIED") supposedly caused to the Reverend Jerry Falwell by the ad parody, Chief Justice William Rehnquist acknowledged the content was "doubtless gross and repugnant in

21. See supra notes $13-16$ and accompanying text.

22. Brandenburg v. Ohio, 395 U.S. 444 (1969). Among other statements, Clarence Brandenburg, using a racial epithet, expressed the undoubtedly offensive sentiment that blacks "should be returned to Africa, the Jew returned to Israel." Id. at 447. He added that "if our President, our Congress, our Supreme Court, continues to suppress the white, Caucasian race, it's possible that there might have to be some revengeance [sic] taken." Id. at 446 .

23. Id. at 447 .

24. Cohen v. California, 403 U.S. 15, 16 (1971) ("The defendant testified that he wore the jacket knowing that the words were on the jacket as a means of informing the public of the depth of his feelings against the Vietnam War and the draft.").

25. Id. at 25-26.

26. Hustler Magazine v. Falwell, 485 U.S. 46, 48 (1988).

27. See generally Clay Calvert \& Robert Richards, Larry Flynt Uncensored: A Dialogue with the Most Controversial Figure in First Amendment Jurisprudence, 9 COMMLAW CONSPECTUS 159 (2001) (providing a comprehensive interview with Flynt, including his reflections on the Falwell case). 
the eyes of most."28 Yet the Court ruled against Falwell, stressing he was a public figure and emphasizing "the fundamental importance of the free flow of ideas and opinions on matters of public interest and concern." 29 Falwell, Rehnquist explained, could only recover for IIED by proving "that the publication contains a false statement of fact which was made with 'actual malice,' i.e., with knowledge that the statement was false or with reckless disregard as to whether or not it was true." 30 That was something Falwell simply could not do; no reasonable person would believe the parody was a factual assertion. ${ }^{31}$

The next year, the Court in Texas v. Johnson protected the right to burn the American flag as a form of symbolic political protest. ${ }^{32}$ In penning the majority opinion, Justice William Brennan explained that "[i]f there is a bedrock principle underlying the First Amendment, it is that the government may not prohibit the expression of an idea simply because society finds the idea itself offensive or disagreeable." 33 He characterized the Court's decision as "a reaffirmation of the principles of freedom and inclusiveness that the flag best reflects, and of the conviction that our toleration of criticism such as Johnson's is a sign and source of our strength." 34

In 1997, the Court held in Reno v. ACLU that two parts of the Communications Decency Act of 1996 ("CDA") that criminalized sexually offensive expressionnamely, what the CDA called "indecent" and "patently offensive" messages — on the Internet violated the First Amendment. ${ }^{35}$ Justice John Paul Stevens explained for the Court that "the many ambiguities concerning the scope of [the CDA's] coverage render it problematic for First Amendment purposes." 36 The imprecision and vagueness issues that riddled the statute were particularly problematic, Stevens pointed out, because the law imposed "a content-based regulation of speech" and carried with it criminal punishment. ${ }^{37}$

28. Falwell, 485 U.S. at 50. Intentional infliction of emotional distress traditionally pivots on "four elements: (1) the defendant's conduct must be intentional or reckless, (2) the conduct must be outrageous and intolerable, (3) the defendant's conduct must cause the plaintiff emotional distress and (4) the distress must be severe." Karen Markin, The Truth Hurts: Intentional Infliction of Emotional Distress as a Cause of Action Against the Media, 5 COMM. L. \& POL'Y 469, 476 (2000).

29. Falwell, 485 U.S. at 50, 57.

30. Id. at 56. The Court in Falwell basically borrowed the actual malice standard from the realm of libel law, where the Court had adopted it in New York Times Co. v. Sullivan, 376 U.S. 254 (1964). In Sullivan, the Court held that public officials suing for libel based upon speech regarding their official conduct must prove that the defamatory statement at issue "was made with 'actual malice' - that is, with knowledge that it was false or with reckless disregard of whether it was false or not." Id. at 297-98. See Nat Stern, The Force of a Legal Concept: The Steady Extension of the Actual Malice Standard, 12 FIRST AMEND. L. REV. 449, 456 (2014) (noting that in Falwell, "the Court not only introduced the actual malice standard to IIED doctrine, but also injected libel's requirement of a false statement of fact into a tort that had not included this element").

31. Falwell, 485 U.S. at 57.

32. Texas v. Johnson, 491 U.S. 397 (1989).

33. Id. at 414 .

34. Id. at 419 .

35. Reno v. ACLU, 521 U.S. 844, 849 (1997).

36. Id. at 870 .

37. Id. at 871,874 . 
Five years later, the Court in Ashcroft v. Free Speech Coalition held that a federal law targeting another form of offensive speech — virtual child pornography ${ }^{38}$ - was unconstitutionally overbroad. $^{39}$ In reaching this determination, Justice Anthony Kennedy, writing for the majority, stated that the statute, among its other flaws, swept up "[a]ny depiction of sexually explicit activity, no matter how it [was] presented." More specifically, it would apply to "a picture in a psychology manual, as well as a movie depicting the horrors of sexual abuse" and "a Renaissance painting depicting a scene from classical mythology." ${ }^{11}$ Kennedy suggested that the statute, which failed to protect speech that had serious literary and artistic value, ${ }^{42}$ might even have applied to then-popular mainstream movies such as Traffic and American Beauty in which it appeared minors were engaged in sexually explicit conduct. ${ }^{43}$

In brief, the Court typically has been highly protective of offensive expression over the past half-century. ${ }^{44}$ Yet this shelter is not absolute. For instance, the Court historically tolerates punishment of offensive expression when language is used in a very narrow context such that it rises to the level of unprotected fighting words. ${ }^{45}$

38. Specifically, the Child Pornography Prevention Act of 1996 made it a crime to possess and distribute "sexually explicit images that appear[ed] to depict minors but were produced without using any real children." Ashcroft v. Free Speech Coal., 535 U.S. 234, 239 (2002). It targeted such images that were "created by using adults who look like minors or by using computer imaging." Id. at 239-40.

39. Free Speech Coal., 535 U.S. at 258. A law is impermissibly overbroad if "a substantial amount of protected speech is prohibited or chilled in the process" of regulating unprotected expression. Id. at 255 .

40. Id. at 246 .

41. Id. at 241,246 .

42. See id. at 246 (noting that the law "prohibits speech despite its serious literary, artistic, political, or scientific value").

43. Id. at $247-48$.

44. See Clay Calvert \& Robert D. Richards, Free Speech and the Right to Offend: Old Wars, New Battles, Different Media, 18 GA. ST. U. L. REV. 671, 676 (2002) ("The general rule is that speech may not be censored solely because some find it offensive.").

45. The Court held more than seventy-five years ago that the regulation of fighting words has "never been thought to raise any Constitutional problem." Chaplinsky v. New Hampshire, 315 U.S. 568, 572 (1942). At that time, it defined fighting words as "those which by their very utterance inflict injury or tend to incite an immediate breach of the peace." Id. The Court later narrowed the definition to "personally abusive epithets which, when addressed to the ordinary citizen, are, as a matter of common knowledge, inherently likely to provoke violent reaction" and that constitute "a direct personal insult." Cohen v. California, 403 U.S. 15, 20 (1971). See Dan T. Coenen, Freedom of Speech and the Criminal Law, 97 B.U. L. REV. 1533, 1548 (2017) (noting that the Court "has-from all appearances-abandoned the notion that certain words are subject to regulation on the theory that 'their very utterance' causes harm").

Thus, the fighting words doctrine targets offensive speech directed at specific individuals. Terri R. Day \& Danielle Weatherby, Speech Narcissism, 70 FLA. L. REV. 839, 867, n.206 (2018) ("Fighting words are offensive words specifically targeted to an individual that would likely cause an average person to fight."). For instance, offensive speech in the form of "racial slurs can constitute fighting words if they are directed at particular individuals and when they are considered in conjunction with the speaker's actions and proximity to the target of the speech." Clay Calvert, Fighting Words in the Era Of Texts, IMs and E-Mails: Can a Disparaged Doctrine be Resuscitated to Punish Cyber-Bullies?, 21 DEPAUL J. ART TECH. \& INTELL. Prop. L. 1, 27 (2010). See In re Spivey, 480 S.E.2d 693, 699 (N.C. 1997) (noting that "[n]o fact is more generally known than that" a white person who openly calls a black person by one especially serious racial epithet "will hurt and anger the black man and often provoke him to confront the white man and retaliate"). 
Perhaps indicating the narrowness of this exception, however, the Court has never upheld another fighting words conviction since it created the exception in 1942. ${ }^{46}$

Beyond fighting words scenarios, the Court has permitted the regulation of offensive but non-obscene expression in three primary settings: (1) public schools; (2) regulatory frameworks where the speaker seeks or is otherwise granted special benefits by a federal agency that polices speech; and (3) when the government itself is deemed to be speaking. The Court's 1986 ruling in Bethel School District v. Fraser exemplifies the first situation. The Court there upheld a public high school's ability to punish a student for delivering what the majority called "a lewd speech at a school assembly" consisting of "an elaborate, graphic, and explicit sexual metaphor." 47 Contrasting the facts of Fraser with those of Cohen v. California, in which the Court safeguarded offensive speech, ${ }^{48}$ Chief Justice Warren Burger reasoned for the majority that "[i]t does not follow ... that simply because the use of an offensive form of expression may not be prohibited to adults making what the speaker considers a political point, the same latitude must be permitted to children in a public school." ${ }^{\prime 9}$ He added, referring to protagonist-speaker Matthew Fraser, that school officials possess authority to "determine that the essential lessons of civil, mature conduct cannot be conveyed in a school that tolerates lewd, indecent, or offensive speech and conduct such as that indulged in by this confused boy." 50

Illustrative of the second situation is Federal Communications Commission v. Pacifica Foundation. ${ }^{51}$ There, the Court in 1978 upheld the statutory power of the FCC to punish radio and television stations for broadcasting indecent speech on the public airwaves even though it does not rise to the level of unprotected obscenity. ${ }^{52}$ Deeming it "undisputed" that the George Carlin "Filthy Words" monologue at issue in the case "was 'vulgar,' 'offensive,' and 'shocking," the Court stressed that the nature of the medium - in this case, broadcasting - is relevant in determining whether such speech is regulatable. ${ }^{53}$ It added that speech in the over-the-air broadcast realm can be controlled more closely than expression in other forms of

46. Burton Caine, The Trouble With "Fighting Words": Chaplinsky v. New Hampshire Is a Threat to First Amendment Values and Should be Overruled, 88 MARQ. L. REV. 441, 445 (2004); ERWIN ChemerinKsy, CONSTitutional LaW PRINCIPLES AND POLiCIES 1053-54 (5th ed. 2015).

47. Bethel Sch. Dist. v. Fraser, 478 U.S. 675, 677-78 (1986).

48. See supra notes 24-25 and accompanying text (addressing Cohen).

49. Fraser, 478 U.S. at 682 .

50. Id. at 683 .

51. FCC v. Pacifica Found., 438 U.S. 726 (1978).

52. See 18 U.S.C. $§ 1464$ (2018) ("Whoever utters any obscene, indecent, or profane language by means of radio communication shall be fined under this title or imprisoned not more than two years, or both.") (emphasis added); Consumer Guide: Obscene, Indecent and Profane Broadcasts, FCC, https:// perma.cc/28LK-EK53 (last visited Oct. 2, 2019) ("Indecent content portrays sexual or excretory organs or activities in a way that does not meet the three-prong test for obscenity."). Obscene expression is unprotected by the First Amendment. See Roth v. United States, 354 U.S. 476, 485 (1957) (concluding that "obscenity is not within the area of constitutionally protected speech or press"); see also Miller v. California, 413 U.S. 15, 24 (1973) (establishing the current three-part test for determining when speech is obscene).

53. Pacifica Found., 438 U.S. at 747, 748 ("We have long recognized that each medium of expression presents special First Amendment problems."). 
media. ${ }^{54}$ That is partly because broadcasters act within a regulatory framework requiring them to serve the public interest and, in turn, conferring them with the benefit of a station license for doing so-a benefit revocable if they fail to nurture that interest. ${ }^{55}$

Indicative of the third scenario is Walker v. Texas Division, Sons of Confederate Veterans. ${ }^{56}$ A five-justice majority held in 2015 that the speech on specialty license plates in Texas is not that of the private individuals who affix such plates to their vehicles, but is rather speech of the State of Texas. ${ }^{57}$ That determination was pivotal in Walker because, as Justice Stephen Breyer wrote for the majority, "[w]hen government speaks, it is not barred by the Free Speech Clause from determining the content of what it says.. ${ }^{58}$ This allowed Texas-without violating the First Amendment - to block a specialty license plate proposed by the Sons of Confederate Veterans that bore an image of a Confederate battle flag that many Texans reportedly found offensive. ${ }^{59}$ Government speech, as Professor Mary-Rose Papandrea observes, is thus "immune to the usual restrictions of the First Amendment." 60 That immunity stretches, as it did in Walker ${ }^{61}$ to the First Amendment's usual bar against censoring speech because it offends and because of the viewpoint expressed. ${ }^{62}$

How does Brunetti and the regulation at issue there fit into this framework of offensive speech cases? Sections B and C below analyze that question.

54. See id. ("And of all forms of communication, it is broadcasting that has received the most limited First Amendment protection.").

55. See id. (noting that "a broadcaster may be deprived of his license and his forum if the Commission decides that such an action would serve "the public interest, convenience, and necessity"').

56. Walker v. Texas Div., Sons of Confederate Veterans, 135 S. Ct. 2239 (2015).

57. See id. at 2246 ("In our view, specialty license plates issued pursuant to Texas's statutory scheme convey government speech.").

58. Id. at 2245 .

59. Id. As Justice Breyer concluded for the majority, "we hold that Texas's specialty license plate designs constitute government speech, and that Texas was consequently entitled to refuse to issue plates featuring SCV's proposed design." Id. at 2253.

60. Mary-Rose Papandrea, The Government Brand, 110 Nw. U. L. REV. 1195, 1197 (2016).

61. The State of Texas in Walker clearly engaged in the same type of viewpoint-based discrimination that the Court in Brunetti found abhorrent to First Amendment principles. Professor Frederick Schauer explains that:

There is no question that Texas rejected the Confederate flag plate precisely because of the point of view it embodied, and no one claimed that a flag embodying the opposite viewpoint - the American flag-would have been excluded. There is thus no plausible argument that Texas's decision was not viewpoint-based. The question was whether this was a form of viewpoint discrimination that the First Amendment prohibits.

Frederick Schauer, Not Just About License Plates: Walker v. Sons of Confederate Veterans, Government Speech, and Doctrinal Overlap in the First Amendment, 2015 Sup. CT. REV. 265, 281-82 (2015).

62. See Clay Calvert, The Government Speech Doctrine in Walker's Wake: Early Rifts and Reverberations on Free Speech, Viewpoint Discrimination, and Offensive Expression, 25 WM. \& MARY BILL RTS. J. 1239, 1243 (2017) ("The government speech doctrine is a powerful weapon in a state's arsenal for expression - one deployable both for promoting the government's own viewpoint and, conversely, for squelching the views of others with which it disagrees."). 


\section{B. VIEWPOINT DISCRIMINATION IS FORBIDDEN}

First and perhaps foremost, Brunetti reinforces the rule that speech causing offense because of the underlying ideas or views conveyed on a topic generally is protected by the First Amendment unless, as noted above, the government speech doctrine applies. ${ }^{63}$ Writing for the Brunetti majority, Justice Kagan-joined by Justices Clarence Thomas, Ruth Bader Ginsburg, Samuel Alito, Neil Gorsuch and Brett Kavanaugh $^{64}$-observed that this principle against viewpoint discrimination was something about which all of the justices in Tam agreed. ${ }^{65}$ As she put it, the "shared conclusion" in Tam was that the disparagement clause was doomed because it permitted viewpoint discrimination. ${ }^{66}$

When does viewpoint discrimination occur? Kagan suggested it arises when a law such as that in Brunetti "distinguishes between two opposed sets of ideas" regarding "the same topics." ${ }^{.67}$ In other words, as the Court wrote twenty-five years ago, viewpoint discrimination goes beyond the government simply targeting a particular subject matter in an evenhanded, viewpoint-neutral fashion to the government actually restraining speech that embraces some views on that subject while allowing others. ${ }^{68}$ The bar against registering immoral marks in Brunetti neatly fit this framework. That is because, as Kagan wrote, it permitted "registration of marks that champion society's sense of rectitude and morality, but not marks that denigrate those concepts." ${ }^{99}$ All nine of the justices in Brunetti, in fact, concluded that the prohibition on immoral marks transgressed the rule against viewpoint discrimination. ${ }^{70}$

The six-justice majority also held that the ban on registering scandalous marks

63. Iancu v. Brunetti, 139 S. Ct. 2294, 2301 (2019) (noting that "a law disfavoring 'ideas that offend' discriminates based on viewpoint, in violation of the First Amendment"). For a discussion of the government speech doctrine, see supra notes 56-62 and accompanying text.

64. Brunetti, 139 S. Ct. at 2295 (identifying the justices who joined Justice Kagan's opinion for the Court).

65. See id. at 2299 (contending that in Tam, the justices "found common ground in a core postulate of free speech law: The government may not discriminate against speech based on the ideas or opinions it conveys").

66. Id.

67. Id. at 2300. This comports with the traditional notion that:

[v]iewpoint regulations go beyond regulating speech on a particular topic or subject matter. They regulate one side of a debate or topic but not the other. In brief, one viewpoint on a particular issue is treated more favorably under a law or court order than another on the same issue.

Clay Calvert, Free Speech and Content-Neutrality: Inconsistent Applications of an Increasingly Malleable Doctrine, 29 MCGEORGE L. REV. 69, 76-77 (1997).

68. See Rosenberger v. Rector \& Visitors of the Univ. of Va., 515 U.S. 819, 829 (1995).

69. Brunetti, 139 S. Ct. at 2299.

70. See id. at 2303 (Roberts, C.J., concurring in part and dissenting in part) ("I agree with the majority that the 'immoral' portion of the provision is not susceptible of a narrowing construction that would eliminate its viewpoint bias."); $i d$. at 2308 (Breyer, J., concurring in part and dissenting in part) ("I agree with the Court ... that the bar on registering 'immoral' marks violates the First Amendment."); id. at 2309 (Sotomayor, J., concurring in part and dissenting in part) (opining with regard to "the word 'immoral,' I agree with the majority that there is no tenable way to read it that would ameliorate the problem" of viewpoint discrimination, and adding that "immoral" "clearly connotes a preference for 'rectitude and morality' over its opposite"). 
violated the principle barring viewpoint discrimination. Justice Kagan explained that this provision allowed the PTO to register "marks when their messages [were in] accord with, but not when their messages def[ied], society's sense of decency or propriety." "71 She elaborated that the "scandalous" clause permitted registration solely of marks "inducing societal nods of approval" and not "those provoking offense and condemnation." 72 In other words, only one side of counterposed views on a topic were registrable - namely, the non-scandalous side. For example, on the subject of drugs, the "scandalous" provision allowed the PTO to block registration for "MARIJUANA COLA" because it glamorized drug abuse, but to grant registration to "D.A.R.E. TO RESIST DRUGS AND VIOLENCE."73 However, and as addressed later, three justices - Roberts, Breyer, and Sotomayor — were willing to narrowly construe the term "scandalous" to spare it from unconstitutionality. ${ }^{74}$

Justice Alito wrote a brief concurrence in Brunetti emphasizing the importance of prohibiting viewpoint discrimination and, in turn, the need for the Court to vigilantly enforce the doctrine barring it. ${ }^{75}$ Calling such discrimination "poison to a free society," Alito contended it is rising in the United States. ${ }^{76}$ Although he failed to identify a single example to support this assertion, it may be that Alito was, sub silentio, pushing back against the majority's holding in Walker, noted above, that permitted viewpoint discrimination against a Confederate battle flag-adorned license plate because government speech ostensibly was at issue. ${ }^{77}$ Importantly, Alito had written a stinging dissent in Walker that was joined by three other conservativeleaning justices. ${ }^{78}$ In it, he contended that Texas had engaged in impermissible viewpoint discrimination and that the majority's decision, penned by Justice Breyer, "establishe[d] a precedent that threatens private speech that government finds displeasing." 79 Thus, it could be that in Brunetti, Alito was still bristling about the viewpoint discrimination that he perceived skated through unchecked in Walker.

While Brunetti reinforces the principle that viewpoint-based discrimination against speech, including viewpoints that cause offense, is presumptively unconstitutional, several justices (and perhaps all) were willing to grant the PTO power to censor marks that offend not because of the idea or viewpoint conveyed, but because of the mode of expression itself. That possible new carve-out for PTO regulation of offensive marks, along with the reasons for it and possible explications of it, are addressed immediately below.

71. Id. at 2300 (majority opinion)

72. Id.

73. Id.

74. See infra Part I.C.

75. See Brunetti, 139 S. Ct. at 2302-03 (Alito, J., concurring).

76. Id. at 2302 (opining that "such discrimination has become increasingly prevalent in this country").

77. See supra notes 56-62 and accompanying text (addressing Walker and the government speech doctrine).

78. See Walker v. Tex. Div., Sons of Confederate Veterans, 135 S. Ct. 2239, 2254 (2015) (Alito, J., dissenting) (noting that Chief Justice John Roberts and Justices Antonin Scalia and Anthony Kennedy joined Alito's dissent).

79. Id. at $2254,2263$. 


\section{Chipping Away at the Wall of Protection for Offensive Speech: The Justices' Concerns About Registering OfFensive Marks AND How They Might Draft a Better Statute Focusing on the Mode of EXPRESSION}

Brunetti indubitably is a free-speech-friendly decision because it struck down the PTO's statutory authority to deny registration for immoral or scandalous marks. Yet none of the nine justices foreclosed the possibility that a better drafted law (or, at least, one more narrowly construed by the justices when it comes to the meaning of "scandalous" marks) might survive First Amendment scrutiny. Before analyzing the different tacks the justices would adopt to provide the PTO with authority to deny registration to certain offensive marks, it helps to understand both: (1) the worries that animated their efforts to salvage the PTO's power in this realm; and (2) the justifications for taking such speech-restrictive action within the regulatory framework of federal trademark law.

\section{Worries About the Future of Trademark Registration}

In terms of frets about what Brunetti augurs for the future, Justice Alito was troubled that it will facilitate registering marks that "further coarsen our popular culture." ${ }^{80}$ In brief, at least for Alito, the PTO needs some authority to police marks to uphold mores of civil communication, particularly when a mark such as FUCT "is not needed to express any idea." ${ }^{\prime \prime 1}$ Alito's unease here parallels the reasoning of his lone dissent in Snyder v. Phelps, an offensive speech case noted earlier. ${ }^{82}$

In Phelps, Alito blasted Westboro Baptist Church ("WBC") members for "launching vicious verbal attacks that make no contribution to public debate." Safeguarding their speech simply was unnecessary, even in "a society in which public issues can be openly and vigorously debated." ${ }^{84}$ Bridging Alito's analysis of the offensive speech at issue in Brunetti and Phelps, the PTO should be allowed to deny registration for FUCT because it does not express any substantive ideas, and it coarsens culture, while the speech of the WBC can be punished in tort law because it does not contribute to public discourse and amounts to decidedly impolite expression. ${ }^{85}$ In brief, low-value speech —expression not essential for conveying ideas (Brunetti) $)^{86}$ and messages failing to contribute to public discourse (Phelps) $)^{87}-$

80. Brunetti, 139 S. Ct. at 2303 (Alito, J., concurring).

81. Id.

82. Snyder v. Phelps, 562 U.S. 443, 463 (2011) (Alito, J., dissenting); see also supra note 13 and accompanying text.

83. Phelps, 562 U.S. at 464.

84. Id. at 475 .

85. Indeed, Alito made it clear the speech was anything but polite when he called it "a malevolent verbal attack." Id. at 463 .

86. See Brunetti, 139 S. Ct. at 2303 (Alito, J., concurring) (suggesting that regulation of vulgar speech that "play[s] no real part in the expression of ideas" can be regulated by the PTO under "a more carefully focused statute" (emphasis added)).

87. See Phelps, 562 U.S. at 474 (Alito, J., dissenting) (concluding that the speech of the WBC members that caused the plaintiff emotional distress "did not relate to a matter of public concern"). 
that offends can be more easily restricted or punished in Justice Alito's legal universe. As the author of this Article contended in 2011, Alito generally "is no friend to expression that offends his personal sense of both morality and substantive merit. In fact, he might be the justice most prone to censor offensive speech on today's High Court." ${ }^{88}$ Although he subsequently delivered the Court's opinion in Tam declaring the disparagement clause unconstitutional, ${ }^{89}$ Alito's opinion there is better viewed as delivering a blow to perceived political correctness rather than as defending offensive expression. ${ }^{90}$

Other justices in Brunetti also expressed qualms about what might result from the case's outcome. For both Justice Breyer and Justice Sotomayor, those fears hinged in no small part on the possibility that attention-grabbing racist epithets might now serve as registered marks, sparking commotion and worse. As Breyer put it, "Just think about how you might react if you saw someone wearing a t-shirt or using a product emblazoned with an odious racial epithet?"91 Similarly, Sotomayor noted that after Brunetti, the PTO will "presumably be compelled to register ... at least one particularly egregious racial epithet." 92 In this vein, she agonized over the "coming rush to register" what she called "the most vulgar, profane, or obscene words and images imaginable." could be forced to sanction and convey legal benefits to, via the PTO's registration process, racist epithets such as the "N word" troubled both Breyer and Sotomayor.

\section{Legal Hooks Upon Which to Hang the PTO's Regulation of Offensive Marks}

If some justices were distressed that Brunetti might coarsen public discourse (Alito) or lead to the registration of racist marks (Breyer and Sotomayor), then the opening or entrée for vesting the PTO with authority to prevent such evils hinges chiefly on the nature of the PTO's regulatory framework. Specifically, that system: (1) confers upon mark holders, via federal registration, tangible legal benefits,${ }^{94}$ as well as the intangible value of perceived government endorsement, but (2) does not

88. Clay Calvert, Justice Samuel A. Alito 's Lonely War Against Abhorrent, Low-Value Expression: A Malleable First Amendment Philosophy Privileging Subjective Notions of Morality and Merit, 40 HofsTRA L. REV. 115, 115 (2011).

89. See supra notes 11-12 and accompanying text.

90. See Calvert, Beyond Trademarks, supra note 10, at 34-35 (contending that Alito's opinion in Tam attacking the disparagement clause may have been "about thwarting political correctness.... This anti-PC motivation is evident when Alito derisively dubs the statute 'a happy-talk clause and when he attacks the government's argument that it 'has an interest in preventing speech expressing ideas that offend," and adding that "Alito's First Amendment stance in Tam may not cut across the free-speech playing field").

91. Brunetti, 139 S. Ct. at 2307 (Breyer, J., concurring in part and dissenting in part).

92. Id. at $2311 \mathrm{n} .5$ (Sotomayor, J., concurring in part and dissenting in part).

93. Id. at 2308

94. See id. at 2297 (majority opinion) (noting that "registration gives trademark owners valuable benefits. For example, registration constitutes 'prima facie evidence' of the mark's validity.... And registration serves as 'constructive notice of the registrant's claim of ownership,' which forecloses some defenses in infringement actions" (citation omitted)). 
prohibit, limit, or otherwise censor their use when registration either is denied by the PTO or is not sought by a user. ${ }^{95}$ In brief, PTO registration confers government benefits; its denial, however, neither thwarts free expression nor curbs a mark's use. ${ }^{96}$

Chief Justice Roberts crisply explained this proposition in Brunetti, writing in his separate opinion that whether marks:

can be registered does not affect the extent to which their owners may use them in commerce to identify goods. No speech is being restricted; no one is being punished. The owners of such marks are merely denied certain additional benefits associated with federal trademark registration. The Government, meanwhile, has an interest in not associating itself with trademarks whose content is obscene, vulgar, or profane. The First Amendment protects the freedom of speech; it does not require the Government to give aid and comfort to those using obscene, vulgar, and profane modes of expression. $^{97}$

Justice Breyer emphasized a similar point. Denial of registration by the PTO works only minor harm to First Amendment speech interests because businesses remain "free to use highly vulgar or obscene words on their products, and even to use such words directly next to other registered marks. Indeed, a business owner might even use a vulgar word as a trademark, provided that he or she is willing to forgo the benefits of registration." 98

Buttressing the proposition that PTO regulation of what he called "highly vulgar or obscene trademarks" was warranted, Breyer stressed that trademark law already is "highly regulated" in order to help consumers identify the source or origin of goods and services. ${ }^{99}$ For Breyer, this carefully focused mission, when coupled with the regulation-intensive nature of federal trademark law, puts applicants like Erik Brunetti on notice that they "should not expect complete freedom to say what [they want], but should instead expect linguistic regulation."100

Breyer's thesis that trademark law is a highly regulated legal space and that speech restrictions are therefore more permissible and expected taps into the point addressed earlier that the Court has greenlighted government regulation of indecent speech within the FCC's regulatory province of over-the-air broadcasting. ${ }^{101}$ As with federal trademark applicants, broadcasters are "accustomed to living in a highly regulated environment" 102 and there is "history of extensive government regulation

95. See id. at 2306 (Breyer, J., concurring in part and dissenting in part) (noting that federal trademark law "leaves businesses free to use highly vulgar or obscene words on their products, and even to use such words directly next to other registered marks," and adding that "a business owner might even use a vulgar word as a trademark, provided that he or she is willing to forgo the benefits of registration"); $i d$. at 2316 (Sotomayor, J., concurring in part and dissenting in part) ("Regardless of whether a trademark is registered, it can be used, owned, and enforced against would-be infringers.").

96. See id. at 2308 (Sotomayor, J., concurring in part and dissenting in part) (describing the federal trademark registration system as "a beneficial governmental initiative").

97. Id. at 2303-04 (Roberts, C.J., concurring in part and dissenting in part).

98. Id. at 2306 (Breyer, J., concurring in part and dissenting in part).

99. Id.

100. Id.

101. See supra notes 51-55 and accompanying text (addressing Pacifica Foundation).

102. Joshua N. Pila, They're Already Regulating the Internet?, 29 COMM. LAWYER 12, 13 (2012). 
of the broadcast medium." 103 First and foremost, broadcasters must agree to serve the public interest in order to be conferred the benefit of a license affording them the right to speak to the public. ${ }^{104}$ Renewal of licenses after eight years by the FCC is also contingent upon serving the public interest. ${ }^{105}$ And although the FCC cannot censor the speech of broadcasters in advance of publication, ${ }^{106}$ Congress has given the agency statutory authority to fine broadcasters - and even to revoke their licenses ${ }^{107}$-if they air obscene, indecent, or profane content, ${ }^{108}$ under the premise that such content is not in the public interest. ${ }^{109}$ Additionally, after Pacifica Foundation, broadcasters have a clear expectation that their speech can be more closely restricted than that conveyed on other forms of media. ${ }^{110}$ The indecency ban simply is "[o]ne of the burdens that licensees shoulder" in exchange for receiving the government-conferred benefit of a license. ${ }^{111}$ Bridging domains, government regulation of offensive speech is more easily understood in the tightly regulated spaces of both trademark law by the PTO and broadcasting by the FCC than it is in other realms that are not as heavily regulated.

Furthermore, as Justice Sotomayor pointed out, trademark registration provides a considerably different context for analyzing the regulation of offensive speech than does the one the Court confronted when it safeguarded the phrase "Fuck the Draft" in Cohen v. California, as described earlier. ${ }^{112}$ While Cohen bestowed First Amendment protection on "the mother of all words commonly labeled lewd or profane," Sotomayor attempted to cabin and confine Cohen's sweep. ${ }^{113}$ Specifically, she stressed that Cohen involved criminal punishment of offensive expression, a far cry from denying the government-granted benefits that flow from PTO registration. ${ }^{114}$ Additionally, Sotomayor emphasized that Cohen was not a case about viewpoint discrimination ${ }^{115}$ —in stark contrast, recall here that the six-justice

\footnotetext{
103. Reno v. ACLU, 521 U.S. 844, 868 (1997).

104. 47 U.S.C. $\S 307$ (a) (2017).

105. Id. §307(c)(1).

106. Id. $\S 326$.

107. See FCC v. Fox Television Stations, Inc., 556 U.S. 502, 506 (2009) (noting that "Congress has given the Commission various means of enforcing the indecency ban, including civil fines ... and license revocations or the denial of license renewals" (citation omitted)).

108. 18 U.S.C. $§ 1464$ (2018).

109. Importantly, the Supreme Court in 2012 made it clear to the FCC that it was "free to modify its current indecency policy in light of its determination of the public interest and applicable legal requirements." FCC v. Fox Television Stations, Inc., 567 U.S. 239, 259 (2012).

110. FCC v. Pacifica Found., 438 U.S. 726, 748 (1978) (noting that "of all forms of communication, it is broadcasting that has received the most limited First Amendment protection").

111. FCC v. Fox Television Stations, Inc., 556 U.S. 502, 506 (2009).

112. Cohen v. California, 403 U.S. 15 (1971); see also supra notes 24-25 and accompanying text.

113. Rodney A. Smolla, Categories, Tiers of Review, and the Roiling Sea of Free Speech Doctrine and Principle: A Methodological Critique of United States v. Alvarez, 76 ALB. L. REv. 499, 501 (2012).

114. See Iancu v. Brunetti, 139 S. Ct. 2294, 2314 (2019) (Sotomayor, J., concurring in part and dissenting in part) ("Cohen arose in the criminal context: Cohen had been arrested and imprisoned under a California criminal statute targeting disturbances of the peace because he was 'wearing a jacket bearing the words ' $\mathrm{F}[* * *]$ the Draft."' (quoting Cohen, 403 U.S. at 16)).

115. Sotomayor explained that the Court in Cohen:

did not suggest that the State had targeted Cohen to suppress his view itself (i.e., his sharp distaste
} 
majority in Brunetti concluded that viewpoint discrimination was fatally present for both the "immoral" and "scandalous" provisions - but rather one that suggests "a plain, blanket restriction on profanity (regardless of the idea to which it is attached) is a viewpoint-neutral form of content discrimination." 116 Or, as the author of this Article wrote in 2019, prior to the Court's ruling in Brunetti but in Tam's aftermath:

"[F]uck" is what offended in Cohen, not Cohen's viewpoint about conscription. "Fuck" is not a viewpoint. It is not even a viewpoint about sex. It is, instead, a word that violates certain norms of civil discourse in polite society and thus gives offense to some people by its very utterance. ${ }^{117}$

Reinforcing the notion that "fuck" is not a viewpoint, Justice Breyer wrote in Brunetti that highly vulgar "words do not typically convey any particular viewpoint."118 In brief, there is a vast legal gulf of contextual differences between, on the one hand, protecting the right to utter "fuck" emotively while expressing political dissent (as in Cohen) and, on the other hand, denying federal trademark registration to deploy "FUCT" as a source identifier for a clothing brand (as in Brunetti). While Cohen is one of the Supreme Court's paramount free expression decisions, ${ }^{119}$ its reach is neither infinite nor elastically all-encompassing when it comes to shielding offensive expression from censorship and restriction. This is particularly true in non-criminal scenarios (such as trademark law in Brunetti) that already feature a high level of federal regulation and where government action-in Brunetti, the act of rejecting registration - does not bar the use of any speech, but simply impedes the receipt of government-conferred benefits. ${ }^{120}$

\section{How the Justices Would Craft a Ban on Offensive Marks}

With these justifications for regulating offensive marks in mind, the next issue is definitional: What constitutes a registration-deniable offensive mark? How, in other words, might Congress - drawing insight from the five opinions in Brunetti-draft a more constitutionally sound statute for the PTO to block the registration of offensive marks? Although mild disagreement exists among their stances, the justices' broad theme is this: Registration of offensive marks may be barred if the PTO focuses solely on obscene, vulgar, or profane modes of expressing ideas, not on the ideas

for the draft), such that it would have accepted an equally colorful statement of praise for the draft (or hostility toward war protesters). Rather, the Court suggested that the State had simply engaged in what later courts would more precisely call viewpoint-neutral content discrimination ...

Id. at 2314-15.

116. Id. at 2315 .

117. Clay Calvert, Merging Offensive-Speech Cases with Viewpoint-Discrimination Principles: The Immediate Impact of Matal v. Tam on Two Strands of First Amendment Jurisprudence, 27 WM. \& MARY BILL OF RTS. J. 829, 836 (2019) [hereinafter Calvert, Merging].

118. Brunetti, 139 S. Ct. at 2306 (Breyer, J., concurring in part and dissenting in part).

119. See Clay Calvert, Revisiting the Right to Offend Forty Years After Cohen v. California: One Case's Legacy on First Amendment Jurisprudence, 10 FIRST AMEND. L. REV. 1, 51 (2011) (addressing how some scholars have lauded Cohen).

120. See Brunetti, 139 S. Ct. at 2306 (Breyer, J., concurring in part and dissenting in part) (noting that "the field at issue here, trademark law, is a highly regulated one with a specialized mission"). 
themselves. More simply, offense caused by how an idea is expressed is regulatable, not the idea itself.

How might such an offensive-mode-of-expression rule play out if implemented by the PTO? Several hypotheticals - albeit ones not posed by the justices in Brunetti - suggest the possibilities. For example, one presumably could register "nonsense" as part of the name mark for a hypothetical business, such as Nonsense Pies, to express the idea that something is untrue, foolish, or deceptive. One presumably could not, however, register "bullshit" as a mark in place of "nonsense" for the same business - now called Bullshit Pies - because "bullshit" might be perceived as a vulgar or profane mode of conveying the underlying idea of untruthfulness or foolishness. Closer to the facts in Brunetti, one seemingly could register "Messed Up Clothing" or "Crazy Clothing," but not "Fucked Up Clothing" because "fucked up" is a profane or vulgar mode of expressing the underlying idea of a messed up or crazy state. Or, harkening back nearly fifty years to Cohen $v$. California, ${ }^{121}$ a hypothetically entrepreneurial Paul Robert Cohen could start a fashion business and register with the PTO "The Draft is Wrong Jackets," but not "Fuck the Draft Jackets," because the latter is a vulgar mode of expressing the former's idea that the draft is misguided, ill-advised, or-more bluntly, but not vulgarly-stupid.

With those hypotheticals in mind, here is how such a regulatory approach ostensibly becomes viable, based on the totality of the Brunetti opinions. In the process, this Article provides context for analyzing and understanding the justices' specific proposals, and it identifies the proposals' seeming strengths and weaknesses.

\section{a. Justice Kagan and the Majority Opinion}

Justice Kagan was clear that her majority opinion said "nothing at all about a statute that covers only" those "marks that offend by their mode of expression," including "lewd, sexually explicit, and profane" ones. ${ }^{122}$ In brief, she left open the possibility that such a statute might pass constitutional muster. Chief Justice Roberts and Justices Alito, Sotomayor, and Breyer, in turn, exploited this regulatory opening by plumbing possibilities for how an offensive-mode-ofexpression statute might be carefully crafted. Their views are described next.

\section{b. Chief Justice Roberts's Opinion}

The solution for the Chief Justice was to define the extant statutory term "scandalous" to encompass "only marks that offend because of their mode of expression-marks that are obscene, vulgar, or profane." 123 Of this three-pronged approach, banning registration of the first category—obscene marks - poses no First Amendment problems. That is because the Supreme Court long ago held that

121. See supra notes 24-25 and accompanying text (addressing Cohen).

122. Brunetti, 139 S. Ct. at 2302 n.* [Note: This is an unnumbered footnote that is designated only by an asterisk].

123. Id. at 2303 (Roberts, C.J., concurring in part and dissenting in part). 
obscenity, as defined by the Court, ${ }^{124}$ is not protected by the First Amendment. ${ }^{125}$

But what about the second and third categories_-vulgar and profane marks? Roberts, unfortunately, proffered no definition for either term. He stressed, however, that denying registration to such marks, along with obscene ones, "does not offend the First Amendment." 126 That is the case, Roberts reasoned, for two related reasons: (1) blocking their registration does not stop one from using them; and (2) the First Amendment does not require the PTO "to give aid and comfort to those using" them. ${ }^{127}$ In other words, the First Amendment is not abridged when Erik Brunetti can still speak freely to the public through an offensive mark and is merely deprived of the government-created benefits that would flow from its registration. The First Amendment, in brief, does not require the PTO to make a decision that bestows upon Brunetti perks above and beyond his simple right to speak.

By way of comparison, the Court held more than thirty years ago in City of Renton v. Playtime Theatres, Inc. that the First Amendment does not require a municipality, when adopting a zoning ordinance for sexually oriented businesses ("SOBs"), to grant SOBs economically favorable locations or ones where it is inexpensive to operate. ${ }^{128}$ As the Court reasoned in Renton, "we have never suggested that the First Amendment compels the Government to ensure that adult theaters, or any other kinds of speech-related businesses for that matter, will be able to obtain sites at bargain prices." 129 It added that the fact that SOBs "must fend for themselves in the real estate market, on an equal footing with other prospective purchasers and lessees, does not give rise to a First Amendment violation." 130 In other words, so long as SOBs are allowed to speak - so long as they are not completely zoned out of a municipality and they have a reasonable opportunity to convey their sexually explicit speech to the public ${ }^{131}$ —no First Amendment violation arises simply because they are deprived of the economic benefits that would have flowed if the government had adopted a more fiscally friendly zoning law. Similarly, so long as holders of vulgar or profane marks are permitted to use them, even after the PTO rebuffs registration, then no First Amendment violation occurs simply because they are denied governmentconferred benefits emanating from registration.

Contextualized more broadly, the notion that the First Amendment is not violated by denying receipt of government benefits comports with the view that the First

124. The three-part test to determine if speech is obscene and thus beyond the purview of First Amendment protection entails considering whether: (1) an average person, applying contemporary community standards, would find that the work, taken as a whole, appeals to the prurient interest; (2) the work depicts or describes, in a patently offensive way, sexual conduct specifically defined by the applicable state law; and (3) the work, taken as a whole, lacks serious literary, artistic, political, or scientific value. Miller v. California, 413 U.S. 15, 24 (1973).

125. See supra note 52 and accompanying text.

126. Brunetti, 139 S. Ct. at 2303 (Roberts, C.J., concurring in part and dissenting in part).

127. Id.

128. City of Renton v. Playtime Theatres, Inc., 475 U.S. 41, 54 (1986)

129. Id.

130. Id

131. See id. ("In our view, the First Amendment requires only that Renton refrain from effectively denying respondents a reasonable opportunity to open and operate an adult theater within the city, and the ordinance before us easily meets this requirement.”). 
Amendment merely extends negative rights against government censorship of speech, not positive ones requiring the government to help promote speech. ${ }^{132}$ Under this conception of negative rights, the First Amendment only provides "freedom from government action. Affirmative or positive liberties are freedoms to particular outcomes, and sometimes require government action to effectuate."133 The First Amendment, indeed, functions as a negative liberty in the trademark realm under Roberts's position. That is because it prevents the PTO from stopping people from using offensive marks; denial of registration, as noted above, does not thwart their use. ${ }^{134}$ The PTO, however, has no affirmative duty to extend a positive right to register a mark and, in turn, to grant its user benefits under federal trademark law. Bluntly put, Erik Brunetti possesses a negative right of free speech barring the PTO from stopping him from using a mark; conversely, he lacks a positive right to receive government registration for that mark and the fiscal advantages it brings.

\section{c. Justice Alito's Opinion}

Although Justice Alito did not use the phrase "mode of expression" or a variant thereof in his solo concurrence, he implied that this tack provides a path forward. He did this by suggesting that Congress should draft a "more carefully focused statute that precludes the registration of marks containing vulgar terms that play no real part in the expression of ideas." 135 As the two emphasized parts of that quotation collectively indicate, a revised statute should focus on certain vulgar terms rather than on the expression of ideas. In other words, it is how an idea is phrasedspecifically, by using a word like "FUCT" that itself "is not needed to express any idea" and, instead, conveys only what Alito called "emotion"- that permits denial of trademark registration without raising constitutional concerns. ${ }^{136}$ This seems strikingly consistent with an approach focusing on the mode of expression, not the conveyance of ideas.

132. See Mary Anne Franks, Fearless Speech, 17 FiRst AmEND. L. Rev. 294, 333 (2018) (noting that "the First Amendment on its face provides a narrow and negative right of free speech" that, when literally interpreted, "only prohibits the creation of federal laws - and after incorporation, state laws - that infringe upon the freedom of speech"); Keith Werhan, The Classical Athenian Ancestry of American Freedom of Speech, 2008 SUP. CT. REV. 293, 297 (2008) (noting that the First Amendment's orientation to free expression "is negative," not positive, because the amendment's language "negates considerable governmental authority to interfere with an individual's freedom of speech, but it imposes few positive obligations on the government to facilitate free speech"); see also Michael J. Gerhardt, The Ripple Effects of Slaughter-House: A Critique of a Negative Rights View of the Constitution, 43 VAND. L. REV. 409, 410 (1990) (describing the interpretation under which "the Constitution in general ... primarily provide[s] negative rights, which require the government to refrain from certain conduct, as opposed to positive rights, which impose affirmative duties on the government to take actions ... to meet the needs of certain citizens").

133. Marvin Ammori, First Amendment Architecture, 2012 WIS. L. REV. 1, 14 (2012).

134. See supra note 95 and accompanying text.

135. Iancu v. Brunetti, 139 S. Ct. 2294, 2303 (Alito, J., concurring) (emphasis added).

136. Id. 


\section{d. Justice Sotomayor's Opinion}

Justice Sotomayor, joined by Justice Breyer, delivered the most comprehensive and specific explication of an offensive-mode-of-expression regulation the PTO could enforce to bar registration of offensive marks. She, like Chief Justice Roberts, ${ }^{137}$ narrowly defined "scandalous" to encompass "only obscenity, vulgarity, and profanity." 138 Although Sotomayor acknowledged this is a content-based regulation, she emphasized it is viewpoint-neutral because it regulates "offensiveness in the mode of communication rather than the idea" and "apart from any particular message."139 This means that it escapes the lethal viewpoint-discrimination designation that, for the six-justice majority, sealed the fate of both the "immoral" and "scandalous" provisions. ${ }^{140}$

How does Sotomayor define vulgarity and profanity? Although not offering a definitive list of vulgar and profane words, she explained that they consist of shocking or extremely offensive terms that fall among "the small group of lewd words or 'swear' words that cause a visceral reaction, that are not commonly used around children, and that are prohibited in comparable settings."141 Something potentially significant about this-and something addressed later in greater detail ${ }^{142}$ - is that Sotomayor favorably cited the Federal Communications Commission's statutory authority over profane language in support of her definition. ${ }^{143}$ This means Brunetti might well breathe new life into the FCC's currently lax enforcement of its own profanity ban by emboldening that agency to enforce it more vigorously. In other words, if a Supreme Court justice in 2019 forcefully calls for one federal agency (the PTO) to enforce a ban on registering profane trademarks, then another federal agency (the FCC) should sense implicit support from at least some members of the Court for it to punish broadcasters who transmit profanity on the public airwaves.

Additionally, Sotomayor cited the Court's holding in Pacifica Foundation, described earlier, to support her definition. ${ }^{144}$ Specifically, she noted that the FCC's objection there was not about a viewpoint expressed by comedian George Carlin, but rather regarded the way he expressed his views. ${ }^{145}$ Perhaps, then, Sotomayor's definition, sub silentio, is confined to the seven words in Carlin's monologue that

137. See supra note 123 and accompanying text (setting forth Roberts's saving definition of "scandalous").

138. Brunetti, 139 S. Ct. at 2308 (Sotomayor, J., concurring in part and dissenting in part).

139. See id. at 2310, 2314 ("A restriction on trademarks featuring obscenity, vulgarity, or profanity is similarly viewpoint neutral, though it is naturally content-based.").

140. See supra note 2 and accompanying text (noting how the Brunetti majority found that both provisions constitute viewpoint-based regulations of speech).

141. Brunetti, 139 S. Ct. at 2311 (Sotomayor, J., concurring in part and dissenting in part). She cited a dictionary definition of "scandalous" in support of this limiting language. Id. at 2309.

142. See infra Part III.

143. Brunetti, 139 S. Ct. at 2311 (Sotomayor, J., concurring in part and dissenting in part); see also 18 U.S.C. § 1464 (2018) (allowing the FCC to fine broadcasters for airing "obscene, indecent, or profane language").

144. See supra notes 51-55 and accompanying text (addressing Pacifica Foundation).

145. Brunetti, 139 S. Ct. at 2311 (Sotomayor, J., concurring in part and dissenting in part). 
triggered the FCCs wrath. ${ }^{146}$

Sotomayor's effort to confine the meaning of vulgarity and profanity to words "not commonly used around children" actually harkens back to a more paternalistic, less egalitarian era when states banned the use of certain language in front of women and children. ${ }^{147}$ Perhaps more prominently, the California statute at issue in Cohen v. California banned, among multiple other things, the "use [of] any vulgar, profane, or indecent language within the presence or hearing of women or children." 148 Today, that same statute omits this language. ${ }^{149}$ A Michigan appellate court in 2002 declared a similar statute that criminalized the "use [of] any indecent, immoral, obscene, vulgar or insulting language in the presence or hearing of any woman or child" unconstitutionally vague. ${ }^{150}$ This statute was later repealed by a 2015 bill. ${ }^{151}$

In a decidedly nebulous fashion, Sotomayor added that "[e]veryone can think of a small number of words (including the apparent homonym of Brunetti's mark) that would ... plainly qualify." 152 The subjectivity and ambiguity of this proposition harkens back more than a half-century to Justice Potter Stewart's famous quip throwing in the metaphorical towel on defining obscenity: "I know it when I see it." 153 The twist for Sotomayor in Brunetti simply is that she-and apparently everyone, in her estimation - knows vulgarity and profanity when they really think about it.

In brief, Sotomayor provided a starting point for defining vulgarity and profanity. Greater definitional clarity, however, is probably needed for a revised statute targeting vulgarity and profanity to survive a void-for-vagueness challenge. ${ }^{154}$ As the Supreme Court described that doctrine when discussing the rules governing another federal regulatory regime-namely, the FCC's enforcement of its antiindecency policies - principles of due process and fair notice require "the invalidation of laws that are impermissibly vague." 155

For example, defining vulgarity - one of the three categories of offensive modes of expression, along with obscenity and profanity, that Sotomayor would allow the PTO to police - seems particularly problematic. That is so in light of the Court's

146. See FCC v. Pacifica Found., 438 U.S. 726, 751 (1978) (quoting the words used by Carlin that he playfully suggested were "the ones that will curve your spine, grow hair on your hands and . . maybe, even bring us, God help us, peace without honor ... um, and a bourbon").

147. Brunetti, 139 S. Ct. at 2311 (Sotomayor, J., concurring in part and dissenting in part).

148. Cohen v. California, 403 U.S. 15, 16 n.1 (1971)

149. Cal. Penal Code $\S 415$ (2019).

150. Michigan v. Boomer, 655 N.W.2d 255, 257 (Mich. Ct. App. 2002).

151. Mich. Comp. LaWs SeRV. $\$ 750.337$ (2002), repealed by PuB. ACts 2015, No. 210, 1 (f), effective Mar. 14, 2016.

152. Brunetti, 139 S. Ct. at 2311 (Sotomayor, J., concurring in part and dissenting in part).

153. Jacobellis v. Ohio, 378 U.S. 184, 197 (1964) (Stewart, J., concurring).

154. See United States v. Williams, 553 U.S. 285, 304 (2008) (observing that a law is void for vagueness if it "fails to provide a person of ordinary intelligence fair notice of what is prohibited, or is so standardless that it authorizes or encourages seriously discriminatory enforcement"); see also Frank D. LoMonte, Fouling the First Amendment: Why Colleges Can 't, and Shouldn't, Control Student Athletes' Speech on Social Media, 9 J. BuS. \& TECH. L. 1, 6-7 (2014) (explaining that a law "may be declared void for vagueness if it fails to give intelligible notice of the behavior that will result in penalties").

155. FCC v. Fox Television Stations, Inc., 567 U.S. 239, 253 (2012). 
wry but sagacious observation in Cohen v. California that "one man's vulgarity is another's lyric" and its contention that "governmental officials cannot make principled distinctions in this area." 156 Thus, if Congress chooses to redraft the statute to deny registration for marks that are vulgar due to their mode of expression, it would face an exceedingly difficult task in pinning down a clear, precise meaning for "vulgar."

Definitional difficulties aside, however, perhaps the true twin hallmarks of Justice Sotomayor's position are her attempts to: (1) doctrinally untangle and separate two distinct modes of judicial analysis: one for examining instances of offense based upon the substantive viewpoint conveyed (offensive viewpoints) and one for reviewing instances of offense arising from the manner of expressing a viewpoint (offensive modes of expression); and (2) reframe the statutory definition of "scandalous" at issue in Brunetti so as to make it fit within the latter category of analysis rather than the former, thereby sparing it (in her view, at least, and should Congress now redraft it as she recommends) from certain doom as a viewpoint-based regulation, while giving it a fighting chance to pass constitutional muster.

In Tam, Justice Alito arguably conflated the two strands of judicial analysis when he bluntly proclaimed that "[g]iving offense is a viewpoint."157 This, as the author of this Article argued prior to the Court's decision in Brunetti, is "oversimplistic."158 A more nuanced position is that "giving offense sometimes may be a viewpoint, but giving offense is not always a viewpoint." "159 In a nutshell, the word "fuck," which was at issue in both Cohen ${ }^{160}$ and Pacifica Foundation, ${ }^{161}$ does not give offense in those disputes because it expresses a viewpoint about the draft or some other topic, but "because its usage 'is a cultural taboo' in terms of how one should speak or talk, and thus it causes offense."162 Put slightly differently, "while viewpointdiscrimination cases are about what substantive idea is being said and censored, offensive-speech cases are about the emotional impact (rather than the cognitive meaning) of speech."163 Justice Sotomayor tapped into the notion of "emotional impact" in Brunetti, writing that the PTO should have power over a small group of words that "cause a visceral reaction." 164

Even if Congress fails to draft a new statute granting the PTO authority to bar registration for marks that offend due to their mode of expression, Justice Sotomayor deserves high praise for her Brunetti opinion. She clarified that there is a doctrinal distinction between cases centering on viewpoint-based discrimination and those

156. Cohen v. California, 403 U.S. 15, 25 (1971).

157. Matal v. Tam, 137 S. Ct. 1744, 1763 (2017).

158. Calvert, Merging, supra note 117, at 837.

159. Id. (emphasis in original).

160. See supra notes 24-25 and accompanying text (addressing Cohen).

161. "Fuck" was one of the seven words in the George Carlin monologue at issue in Pacifica Foundation). See supra note 146.

162. Calvert, Merging, supra note 117, at 834 (quoting Christopher Fairman, Fuck, 28 CARDOZO L. REV. 1711, 1722 (2007)).

163. Id. at 836 (emphasis in original).

164. Iancu v. Brunetti, 139 S. Ct. 2294, 2311 (2019) (Sotomayor, J., concurring in part and dissenting in part). 
pivoting on words that give offense regardless of a viewpoint. Justice Alito's sweeping assertion in Tam that "[g]iving offense is a viewpoint"165 muddled the two doctrinal strands of cases; ${ }^{166}$ Justice Sotomayor's opinion in Brunetti halts that confusion.

Finally, and to lend long-standing doctrinal support to her view, Sotomayor's mode-of-expression logic for barring registration of offensive marks taps into the reasoning behind the Court's fighting words carve-out from First Amendment protection. ${ }^{167}$ Specifically, as Justice Antonin Scalia wrote in the cross-burning case of R.A.V. v. City of St. Paul, "the reason why fighting words are categorically excluded from the protection of the First Amendment is not that their content communicates any particular idea, but that their content embodies a particularly intolerable (and socially unnecessary) mode of expressing whatever idea the speaker wishes to convey."168 In other words, the underlying "ideas conveyed by fighting words are constitutionally protected." 169 This is significant because if fighting words are punishable due to a speaker's use of a mode of expression deemed intolerable and socially unnecessary, as Justice Scalia put it in R.A.V., ${ }^{170}$ then the PTO should possess the authority to deny registration for marks whose mode of expression is similarly intolerable and socially unnecessary when it comes to helping consumers distinguish between the source or origin of goods or services.

\section{e. Justice Breyer's Opinion}

Although Justice Breyer joined Justice Sotomayor's opinion, ${ }^{171}$ he also wrote separately, concurring in part and dissenting in part. ${ }^{172}$ As this Article discusses later in Section A of Part II, a large chunk of Breyer's opinion attacks the Court's traditional methodology in free speech cases and extols the virtues of proportionality. ${ }^{173}$ Part of his opinion, however, articulates a slightly different conception of the marks for which he believes the PTO can deny registration without violating the First Amendment.

In particular, Breyer averred that the PTO should be able to refuse registration for marks that are "highly vulgar or obscene" 174 by interpreting the statutory word "scandalous" in such a narrow and limiting fashion. ${ }^{175}$ As he explained, the

165. Matal v. Tam, 137 S. Ct. 1744, 1763 (2017).

166. Calvert, Merging, supra note 117, at 842.

167. See Brunetti, 139 S. Ct. at 2314 (Sotomayor, J., concurring in part and dissenting in part) (citing the Court's fighting words doctrine to support the idea that a mode-of-expression classification may be independent from any viewpoint expressed).

168. R.A.V. v. City of St. Paul, 505 U.S. 377, 393 (1992) (emphasis in original).

169. Kindaka J. Sanders, Defending the Spirit: The Right to Self-Defense Against Psychological Assault, 19 NEV. L.J. 228, 246 (2018).

170. R.A.V., 505 U.S. at 393.

171. See Brunetti, 139 S. Ct. at 2308 (Sotomayor, J., concurring in part and dissenting in part) (noting that Breyer joined Sotomayor's opinion).

172. See id. at 2304 (Breyer, J., concurring in part and dissenting in part).

173. See infra Part II.A.

174. Brunetti, 139 S. Ct. at 2307 (Breyer, J., concurring in part and dissenting in part)

175. See id. at 2304 (expressing his agreement "with Justice Sotomayor that, for the reasons she 
government has "at least a reasonable interest in ensuring that it is not involved in promoting highly vulgar or obscene speech, and that it will not be associated with such speech." 176

Three items immediately stand out when his position is compared to the calls of Chief Justice Roberts, Justice Sotomayor, and Justice Alito for the sorts of marks that should be denied registration. Roberts and Sotomayor, it will be recalled, both argued that the PTO needs authority to rebuff registration for obscene, vulgar, or profane marks that cause offense due to their mode of expression. ${ }^{177}$ Justice Alito, as noted earlier, focused more narrowly on vulgar marks, not mentioning obscene or profane ones. ${ }^{178}$ The first item, then, is one of consistency among Breyer, Roberts, Alito, and Sotomayor: They all would vest the PTO with authority over vulgar marks. The second point, conversely, is one of contrast; Breyer is the only justice to modify vulgar with the adverb "highly." Finally, the third item is another one of contrast: Breyer and Alito omit the term "profanity," while Roberts and Sotomayor adopt it.

Are these two distinctions significant? First, Breyer's effort to dial up the level of vulgarity necessary to warrant PTO denial of registration, via the modifier "highly," carries both pros and cons. On the positive side, at least from a pro-freespeech perspective, it reins in the PTO's discretion to determine which marks may be denied registration - namely, only those that are highly vulgar. In fact, this attempt to restrain the scope of vulgarity is consistent with Justice Sotomayor's position. While she did not modify "vulgar" with the adverb "highly," Sotomayor explained that the statutory term "scandalous," which she narrowed in construction to include only obscene, vulgar, and profane marks, swept up only those vulgar marks that are shocking and extremely offensive. ${ }^{179}$ In brief, Breyer's use of "highly" approximates Sotomayor's use of "extremely" when it comes to defining the ambit of vulgarity, with both jurists limiting regulatable vulgarity to some unspecified upper stratum.

On the negative side, the adverb "highly" itself seems imprecise and subjective. While "highly" clearly suggests a greater level of vulgarity beyond what would be, by contrast, "moderately" vulgar, the threshold for clearing "highly" might vary from person to person based upon, perhaps, how much vulgarity she is used to hearing or

gives, we should interpret the word 'scandalous' in the present statute to refer only to certain highly 'vulgar' or 'obscene' modes of expression").

176. Id. at 2307 (emphasis added).

177. See id. at 2303 (Roberts, C.J., concurring in part and dissenting in part) (opining that "refusing registration to obscene, vulgar, or profane marks does not offend the First Amendment"); id. at 2313 (Sotomayor, J., concurring in part and dissenting in part) ("Adopting a narrow construction for the word "scandalous"-interpreting it to regulate only obscenity, vulgarity, and profanity-would save it from unconstitutionality.")

178. See id. at 2303 (Alito, J., concurring) ("Our decision does not prevent Congress from adopting a more carefully focused statute that precludes the registration of marks containing vulgar terms that play no real part in the expression of ideas." (emphasis added)).

179. See id. at 2311 (Sotomayor, J., concurring in part and dissenting in part) ("Of course, 'scandalous' offers its own limiting principle: if a word, though not exactly polite, cannot be said to be 'scandalous' - e.g., 'shocking' or 'extremely offensive,' 8 CENTURY DICTIONARY 5374 - it is clearly not the kind of vulgarity or profanity that Congress intended to target."). 
reading. In brief, it might be that the more prudish and proper a person is, the more likely she is to regard a mark as highly vulgar, whereas someone who is comfortable with swearing would be less likely to find the same mark highly vulgar. One solution, of course, is to deploy a fictional average person test: Would an average person deem the vulgarity highly offensive? For example, the Supreme Court uses an average-person standard - in particular, an average-adult test - in the realm of obscenity law. ${ }^{180}$ The Court thus seemingly would be comfortable with Congress embracing an average-person test for high vulgarity in the trademark context.

In terms of the second difference, Breyer's (like Alito's) omission of "profanity" streamlines the definition, thereby helping Congress (should it redraft the statute) by eliminating another term that, like "vulgarity," is fraught with definitional ambiguities and ripe for a void-for-vagueness challenge. For instance, and as described in Part III, ${ }^{181}$ the Federal Communications Commission rather cryptically defines profanity as "'grossly offensive' language that is considered a public nuisance."182 Whether the FCC's modification of the vague term "offensive" with the adverb "grossly" clarifies anything about what is profane is debatable, ${ }^{183}$ but it is somewhat akin to Breyer modifying "vulgar" with "highly" to limit its scope by heightening the degree of vulgarity. ${ }^{184}$ Ultimately, as one scholarly article notes in reviewing the FCC's regulation of profanity, "[t]he term 'profane language' admits no easy definition, let alone general agreement regarding its place in American society and the extent to which the government should attempt to regulate it." 185

Whether "profanity" carries a different meaning from "vulgarity" today or whether they are duplicative is another issue Congress would need to tackle were it to adopt the approach of Roberts and Sotomayor in limiting the meaning of "scandalous" to modes of expression that cause offense because they are obscene, vulgar, or profane. Jettisoning the term "profane," by contrast, renders the benefit of

180. See Miller v. California, 413 U.S. 15, 33 (1973) (noting that the "primary concern" of having a jury apply the average-person standard for obscenity is that "so far as material is not aimed at a deviant group, it will be judged by its impact on an average person, rather than a particularly susceptible or sensitive person"); see also Pinkus v. United States, 436 U.S. 293, 300 (1978) (observing that "the community includes all adults who constitute it, and a jury can consider them all in determining relevant community standards"); ACLU v. Ashcroft, 322 F.3d 240, 246 (3d Cir. 2003) (noting that "Miller applied such standards as related to the average adult").

181. See infra Part III (addressing whether Brunetti might embolden the Federal Communications Commission to enforce its statutory power over profane language on the broadcast airwaves).

182. Consumer Guide: Obscene, Indecent and Profane Broadcasts, FCC, https://perma.cc/28LKEK53 (last visited Oct. 2, 2019).

183. See Clay Calvert, The FCC and Profane Language: The Lugubrious Legacy of a Moral Panic and a Grossly Offensive Definition That Must be Jettisoned, 17 FIRST AMEND. L. REV. 147, 173-74 (2018) (calling it "hard to fathom how using the word 'grossly' to modify 'offensive' adds clarity for a broadcaster seeking guidance and fair notice on how to avoid a possible civil penalty for airing profane content," and asserting that "[a]ll 'grossly' does is ratchet up the level of offensiveness, but to an unspecified and nebulous degree").

184. See supra notes 174-176 and accompanying text (addressing Breyer's use of the term "highly vulgar").

185. Edward L. Carter, R. Trevor Hall \& James C. Phillips, Broadcast Profanity and the "Right to Be Let Alone": Can the FCC Regulate Non-Indecent Fleeting Expletives Under a Privacy Model?, 31 HASTINGS COMM. \& ENT. L.J. 1, 2 (2008). 
simplifying Congress's definitional task to explicating only one word ("vulgarity"), given that the Supreme Court already has defined "obscenity."186

In summary, all nine justices in Brunetti left open the possibility that the PTO could regulate marks that offend due solely to their mode of expression. Roberts, Sotomayor, and Breyer fleshed out what such a mode-of-expression definition might look like were Congress to draft a new statute adopting their efforts to more precisely construe "scandalous," as used in the statute the Brunetti majority struck down. Additionally, Justice Alito, although unwilling to provide such a narrowing construction to save the term "scandalous," 187 suggested that a more narrowly drafted statute targeting only vulgarity not conveying a substantive idea would be permissible. ${ }^{188}$ In total, four members of the Court telegraphed to Congress specific ways of resuscitating the PTO's power over a narrow class of offensive marks. This Part has critiqued those efforts and contextualized them within a framework of related First Amendment principles, doctrines, and cases.

The next Part of this Article moves beyond these definitional issues to address Justice Breyer's efforts in Brunetti to once again instantiate proportionality review into First Amendment jurisprudence. Furthermore, the next Part also examines Justice Sotomayor's contention that strict scrutiny need not apply to measure the constitutional validity of a mode-of-expression rule for offensive marks that would empower the PTO to bar their registration.

\section{OF PROPORTIONALITY AND SCRUTINY: A CLOSER LOOK AT BRUNETTI}

This Part has two sections. Section A concentrates on Justice Breyer's articulation in Brunetti of his proportionality approach to First Amendment disputes and how he applied it to the facts of the case. Section B examines Justice Sotomayor's suggestion that an offensive-mode-of-expression regulation enforced by the PTO, although content-based, would not need to surmount strict scrutiny review to be constitutional. Viewed collectively, the opinions of Breyer and Sotomayor reveal that not all of the justices believe strict scrutiny presumptively applies simply because a statute is facially content-based. This is particularly significant in light of the Court's 2015 ruling in Reed $v$. Town of Gilbert arguably suggesting otherwise. ${ }^{189}$

186. See supra note 124 and accompanying text (setting forth the Court's three-part test for obscenity developed in Miller v. California, 413 U.S. 15 (1973)).

187. Iancu v. Brunetti, 139 S. Ct. 2294, 2302-03 (Alito, J., concurring) (expressing his unwillingness to provide a saving construction for the statute by asserting that the law at issue "cannot be fixed without rewriting the statute" and adding that "we are not legislators and cannot substitute a new statute for the one now in force").

188. See id. at 2303 ("Our decision does not prevent Congress from adopting a more carefully focused statute that precludes the registration of marks containing vulgar terms that play no real part in the expression of ideas.").

189. Reed v. Town of Gilbert, 135 S. Ct. 2218 (2015). Writing for the majority, Justice Clarence Thomas opined that "[c]ontent-based laws - those that target speech based on its communicative content - are presumptively unconstitutional and may be justified only if the government proves that they are narrowly tailored to serve compelling state interests." $I d$. at 2226 . He added that this means that facially content-based laws "are subject to strict scrutiny." $I d$. at 2227. For analysis of Justice Thomas's 
Furthermore, this Part contends that a carefully crafted offensive-mode-ofexpression rule that focuses only on the manner of expression provides an escape hatch from strict scrutiny because it evades the Court's reasoning in Reed that "[g]overnment regulation of speech is content based if a law applies to particular speech because of the topic discussed or the idea or message expressed."190 In brief, as explored in Section B, an offensive-mode-of-expression rule applies regardless of the topics, ideas, or substantive messages being addressed.

\section{A. Justice Breyer: Doctrinal Categories, Rules of Thumb and Proportionality}

It is somewhat safe to say, after reading Justice Breyer's opinion in Brunetti, that he mildly objects to the Court's decades-old approach to analyzing free speech cases. Actually, that is an understatement. A more accurate conclusion is that Breyer, among all his high court colleagues, ${ }^{191}$ is the most willing to obliterate the Court's

opinion, see Dan V. Kozlowski \& Derigan Silver, Measuring Reed's Reach: Content Discrimination in the U.S. Circuit Courts of Appeals After Reed v. Town of Gilbert, 24 COMM. L. \& POL'Y 191, 192 (2019) (noting that Thomas's opinion "seemed to have the potential to throw many regulations into jeopardy and reshape First Amendment jurisprudence" because he "wrote in broad strokes, as if all content-based laws, even those that target less protected areas of speech such as commercial speech, should be subjected to strict scrutiny" and because Thomas opined that "that facial content discrimination cannot be saved with a benign purpose") (emphasis in original).

190. Reed, 135 S. Ct. at 2227 (emphasis added).

191. See Donald L. Beschle, Fake News, Deliberate Lies, and the First Amendment, 44 DAYTON L. REV. 209, 219 (2019) (describing Breyer as "the Court's most frequent advocate of invoking a proportionality (or balancing) test in constitutional cases"); Mark Tushnet, Internet Exceptionalism: An Overview from General Constitutional Law, 56 WM. \& MARY L. REV. 1637, 1640 n.9 (2015) ("The primary expositor of proportionality analysis, including in connection with the First Amendment, is Justice Stephen Breyer."). 
traditional categorical-exclusion ${ }^{192}$ and labeling ${ }^{193}$ methodology. He also is the most willing to jettison its tiers-of-scrutiny tack that typically pivots on a content-based versus content-neutral dichotomy ${ }^{194}$ for analyzing restrictions on speech that is presumptively protected by the First Amendment. ${ }^{195}$ Breyer would replace it all with

192. Under this approach, the Court embraces the notion that some categories of speech are either of such low value that restricting them does not raise any First Amendment concerns or, more recently, that there is a historical tradition of not protecting such speech. See Chaplinsky v. New Hampshire, 315 U.S. 568, 571-72 (1942) (marking the start of this approach via the assertion that " $[\mathrm{t}] \mathrm{here}$ are certain welldefined and narrowly limited classes of speech, the prevention and punishment of which have never been thought to raise any Constitutional problem," and adding that these categories include "the lewd and obscene, the profane, the libelous, and the insulting or "fighting' words" which "are no essential part of any exposition of ideas, and are of such slight social value as a step to truth that any benefit that may be derived from them is clearly outweighed by the social interest in order and morality"); United States v. Stevens, 559 U.S. 460, 472 (2010) (asserting that whether a category of speech falls outside of First Amendment protection depends on whether it has "been historically unprotected"); see also Wayne Batchis, On the Categorical Approach to Free Speech - And the Protracted Failure to Delimit the True Threats Exception to the First Amendment, 37 PACE L. REV. 1, 2 (2016) (noting that the Court's "famous dictum" from its ruling in Chaplinsky "is responsible for establishing this system of classification"); Chad Flanders, A Half-Hearted Defense of the Categorical Approach, 95 WASH. U. L. REV. 1389, 1393 (2018) (noting that "the list of categorical exceptions to First Amendment protection" gives rise to "the name, the 'categorical approach"'); Gregory P. Magarian, The Marrow of Tradition: The Roberts Court and Categorical First Amendment Speech Exclusions, 56 WM. \& MARY L. REV. 1339, 1342-43 (2015) (observing that "[t]he development of categorical speech exclusions stretches back to the beginning of First Amendment law," and asserting that the Supreme Court's 1942 decision in Chaplinsky "modeled the categorical approach to setting the First Amendment's boundaries").

193. Ronald J. Krotoszynski, Jr., Our Shrinking First Amendment: On the Growing Problem of Reduced Access to Public Property for Speech Activity and Some Suggestions for a Better Way Forward, 78 OHIO ST. L.J. 779, 795 (2017) (noting that labeling "speech as 'political,' 'commercial,' or 'obscene' often prefigures its protected or unprotected status under the First Amendment").

194. Lillian R. BeVier, The First Amendment on the Tracks: Should Justice Breyer Be at the Switch?, 89 MiNN. L. REV. 1280, 1294 (2005) ("The use of the content-based/content-neutral distinction as a trigger for the level of scrutiny is entrenched in First Amendment doctrine.").

195. Under the Court's tiers-of-scrutiny approach in First Amendment speech cases, content-based regulations typically are subject to strict scrutiny review, while content-neutral regulations generally must survive intermediate scrutiny. As Professor Genevieve Lakier explains it:

The distinction between content-based and content-neutral regulations of speech is one of the most important in First Amendment law. For decades now, the Supreme Court has insisted that contentbased laws - laws that restrict speech because of its ideas or messages or subject matter-are presumptively unconstitutional, and will be sustained only if they can satisfy strict scrutiny. In contrast, content-neutral laws - laws that regulate speech for some reason other than its contentare reviewed under a lesser, and often quite deferential, standard.

Genevieve Lakier, Reed v. Town of Gilbert, Arizona, and the Rise of the Anticlassificatory First Amendment, 2016 SuP. CT. Rev. 233, 233. See Ashutosh Bhagwat, Producing Speech, 56 WM. \& MARY L. REV. 1029, 1062 (2015) ("It is of course familiar grounds in First Amendment jurisprudence that content-based laws are of greater constitutional concern than content-neutral laws. For restrictions on speech itself, the doctrine imposes strict scrutiny on content-based laws and a relatively deferential form of intermediate scrutiny for content-neutral laws."); see also Enrique Armijo, The "Ample Alternative Channels" Flaw in First Amendment Doctrine, 73 WASH. \& LEE L. REV. 1657, 1691 (2016) (noting that "the content-based versus content-neutral distinction ... governs Speech Clause doctrine").

There are, however, some exceptions to the rule that content-based laws are subject to strict scrutiny. For instance, statutes targeting truthful commercial speech for lawful goods and services are subject to a form of intermediate scrutiny review. See Tamara R. Piety, Market Failure in the Marketplace of Ideas: Commercial Speech and the Problem that Won't Go Away, 41 LOY. L.A. L. REV. 181, 182 (2007) (observing that "the commercial speech doctrine creates a category of speech subject to intermediate 
a more "free-form"196 proportionality framework adopted in Europe but generally not embraced in the United States. ${ }^{197}$

Justice Breyer, as former Stanford Law School Dean Kathleen Sullivan observes, devotes greater attention "to consequences rather than categories" and "favors flexibility." 198 Indeed, Breyer's penchant for flexibility and elasticity ${ }^{199}$ and his concomitant disdain of categories was front and center in Brunetti. As he bluntly wrote there, the Court should treat its "speech-related categories not as outcomedeterminative rules, but instead as rules of thumb."200

It was not the first time Breyer had argued that the Court's doctrinal categories are mere rules of thumb. He did the same thing in both Reed v. Town of Gilbert ${ }^{201}$ and Pleasant Grove City v. Summum. ${ }^{202}$ In the former case, he argued that " $[\mathrm{t}] \mathrm{he}$ First Amendment requires greater judicial sensitivity both to the Amendment's

scrutiny under the First Amendment"); Judith Welch Wegner \& Matthew Norchi, Regulating Panhandling: Reed and Beyond, 63 S.D. L. REV. 579, 593 (2019) (noting that "commercial speech generally only invokes intermediate scrutiny").

196. See Vikram David Amar \& Alan Brownstein, The Voracious First Amendment: Alvarez and Knox in the Context of 2012 and Beyond, 46 LOY. L.A. L. REV. 491, 497 (2013) (noting that Breyer tends to engage in a "free-form balancing approach").

197. For the place of proportionality in European jurisprudence, see George A. Bermann, Taking Subsidiarity Seriously: Federalism in the European Community and the United States, 94 CoLum. L. ReV. 332, 387 (1994) ("Proportionality ... has chiefly been regarded in the European Community, and in European public law more generally, as a principle of judicial review.”); Moshe Cohen-Eliya \& Iddo Porat, The Hidden Foreign Law Debate in Heller: The Proportionality Approach in American Constitutional Law, 46 SAN DIEGO L. REV. 367, 380 (2009) (noting "the well-known European doctrine of proportionality"); Thomas M. Franck, On Proportionality of Countermeasures in International Law, 102 AM. J. INT'L L. 715, 752 (2008) (“The principle of proportionality is deeply ingrained in the national jurisprudence of the civil law states of Europe, and this has affected the development of proportionality as an important legal precept both in European regional law and, more generally, in international law.”). For the lack of support for proportionality in the United States, see Vicki C. Jackson, Ambivalent Resistance and Comparative Constitutionalism: Opening up the Conversation on "Proportionality," Rights and Federalism, 1 U. PA. J. CONST. L. 583, 603 (1999) (noting that "U.S. constitutional law does not ordinarily and explicitly resort to the idea of proportionality as a measure of constitutionality").

198. Kathleen M. Sullivan, Tribute to Justice Stephen G. Breyer, 64 N.Y.U. ANN. SURV. AM. L. 25, 27 (2008).

199. See Benjamin Pomerance, An Elastic Amendment: Justice Stephen G. Breyer's Fluid Conceptions of Freedom of Speech, 79 ALB. L. REV. 403, 507 (2016) (asserting that Breyer views the First Amendment as "an elastic amendment, expanding and contracting depending on the interests that each side asserted for the dispute currently before the Court").

200. Iancu v. Brunetti, 139 S. Ct. 2294, 2304 (2019) (Breyer, J., concurring in part and dissenting in part).

201. Breyer wrote in Reed that when it comes to analyzing cases that regulate specific types of content:

The better approach is to generally treat content discrimination as a strong reason weighing against the constitutionality of a rule where a traditional public forum, or where viewpoint discrimination, is threatened, but elsewhere treat it as a rule of thumb, finding it a helpful, but not determinative legal tool, in an appropriate case, to determine the strength of a justification.

Reed v. Town of Gilbert, 135 S. Ct. 2218, 2235 (2015) (Breyer, J., concurring) (emphasis added). He added in Reed that "the category 'content discrimination' is better considered in many contexts, including here, as a rule of thumb, rather than as an automatic 'strict scrutiny' trigger, leading to almost certain legal condemnation." Id. at 2234 (emphasis added).

202. In Summum, Breyer contended "that the 'government speech' doctrine is a rule of thumb, not a rigid category." City of Pleasant Grove v. Summum, 555 U.S. 460, 484 (2009) (Breyer, J., concurring). 
expressive objectives and to the public's legitimate need for regulation than a simple recitation of categories, such as 'content discrimination' and 'strict scrutiny,' would permit.". 203 In the latter, he contended that the Court, rather than "turn[ing] 'free speech' doctrine into a jurisprudence of labels," 204 should instead "ask whether a government action burdens speech disproportionately in light of the action's tendency to further a legitimate government objective."205

It is the last Breyer quotation above from Summum that encapsulates his view of proportionality, which he reiterated in Brunetti. In Brunetti, Breyer explicitly: (1) rebuffed "existing outcome-determinative categories;" 206 (2) engaged in "proportionality analysis;" 207 and (3) called for the Court to "focus on the interests the First Amendment protects and ask a more basic proportionality question: Does 'the regulation at issue wor[k] harm to First Amendment interests that is disproportionate in light of the relevant regulatory objectives'?"208

A key principle for Breyer-focusing on the underlying interests and values that the First Amendment is intended to protect or, as he put it in Reed, on the First Amendment's "expressive objectives"209_builds directly upon his dissent just one year earlier in National Institute of Family \& Life Advocates v. Becerra. ${ }^{210}$ In Becerra, five conservative justices held that two compelled-disclosure requirements affecting crisis pregnancy centers in California likely violated their First Amendment speech rights. ${ }^{211}$ Authoring a dissent joined by fellow liberal-leaning Justices Ruth Bader Ginsburg, Sonia Sotomayor, and Elena Kagan, Breyer asserted that the majority's suggestion "that heightened scrutiny applies to much economic and social legislation" simply because it is content-based is misguided. ${ }^{212}$ That is because, in Breyer's view, these laws do not jeopardize "the true value of protecting freedom of

203. Reed, 135 S. Ct. at 2234 (Breyer, J., concurring).

204. Summum, 555 U.S. at 484 (Breyer, J., concurring).

205. Id.

206. Iancu v. Brunetti, 139 S. Ct. 2294, 2306 (2019) (Breyer, J., concurring in part and dissenting in part).

207. Id.

208. Id. (quoting Reed, 135 S. Ct. at 2235-36 (Breyer, J., concurring)).

209. Reed v. Town of Gilbert, 135 S. Ct. 2218, 2234 (2015) (Breyer, J., concurring); see also Brunetti, 139 S. Ct. at 2305 (Breyer, J., concurring) (stating that he "would appeal more often and more directly to the values the First Amendment seeks to protect" (emphasis added)).

210. Nat'l Inst. of Family \& Life Advocates v. Becerra, 138 S. Ct. 2361 (2018).

211. As summed up by Justice Clarence Thomas in writing the majority opinion in Becerra on behalf of himself, Chief Justice John Roberts, and Justices Anthony Kennedy, Samuel Alito, and Neil Gorsuch, the California statute required licensed crisis pregnancy centers to "notify women that California provides free or low-cost services, including abortions, and give them a phone number to call." Id. at 2368. It also mandated that unlicensed crisis pregnancy centers disclose the fact that they are not, in fact, licensed by California to provide medical services. Id. The centers, which are pro-life organizations that aim to dissuade women from obtaining abortions, argued that these mandates violated their First Amendment right of free expression by compelling them to convey government-drafted messages that would alter their own pro-life message. Id. at 2368-71. The majority held that the centers were "likely to succeed on the merits of their claim." Id. at 2378.

212. Becerra, 138 S. Ct. at 2382 (Breyer, J., dissenting); see also id. at 2380 ("Before turning to the specific law before us, I focus upon the general interpretation of the First Amendment that the majority says it applies. It applies heightened scrutiny to the Act because the Act, in its view, is 'content based."' (quoting $i d$. at 2371 (majority opinion))). 
speech."213 Acknowledging that the "true value[s]" include safeguarding both unpopular ideas and a marketplace of ideas where truth may win out, Breyer reasoned that the majority's tack does "those First Amendment goals a serious disservice through dilution." 214 While not phrasing it in terms of proportionality, Breyer's thesis in Becerra smacks of a proportionality approach: Applying heightened scrutiny to "ordinary economic and social legislation"215 is misguided and unnecessary — it is, in other words, a disproportionately heavy-handed test—because the damage worked to core First Amendment interests from such legislation generally is minimal.

Breyer's proportionality approach thus first entails reviewing the speech interests at stake in any case and, specifically, whether a statute affects "values the First Amendment seeks to protect." 216 Put differently, the threshold issue for Breyer is whether a statute impacts important interests that the First Amendment is intended to protect. The second step then considers whether the damage wrought to those speech interests - be they core First Amendment values or ones peripheral to that amendment's purpose - is disproportionate when compared to the government's interest in achieving its regulatory objectives by restricting speech. ${ }^{217}$

Proportionality in First Amendment cases, which Justice Breyer asserts "involves balancing," 18 boils down to evaluating whether "statutes strike a reasonable balance between their speech-restricting and speech-enhancing consequences" 219 or, in contrast, whether the "restrictions on speech . . . are disproportionate when measured against their corresponding . . . benefits. ${ }^{.20}$ More simply put by Professor Carmen Maye in a recent article, a law will pass constitutional muster if the interference with speech interests is "in proportion to the interests served" by that interference. ${ }^{221}$

The presumptions in this balancing approach seem to be as follows: (1) When a statute implicates core First Amendment interests and values, less incursion upon speech is allowed when serving a government's regulatory objective; and, conversely, (2) when core First Amendment interests and values are not implicated by a statute, greater incursion upon speech is permissible to facilitate a government's regulatory objective. Parsed differently, whether statutory encroachment on speech

\footnotetext{
213. Id. at 2383

214. Id. at $2382-83$

215. Id. at 2381 .

216. Iancu v. Brunetti, 139 S. Ct. 2294, 2305 (2019) (Breyer, J., concurring in part and dissenting in part).

217. Sorrell v. IMS Health Inc., 564 U.S. 552, 582 (2011) (Breyer, J., dissenting).

218. StePhen Breyer, MAKING OUR DEMOCRACY WORK: A JUdGE'S VIEW 164 (2010).

219. Bartnicki v. Vopper, 532 U.S. 514, 536 (2001) (Breyer, J., concurring).

220. Id. See also United States v. Alvarez, 567 U.S. 709, 730 (2012) (Breyer, J., concurring) (contending that in First Amendment cases, the Court must decide if a "statute works speech-related harm that is out of proportion to its justifications"); Nixon v. Shrink Mo. Gov't PAC, 528 U.S. 377, 402 (2000) (Breyer, J., concurring) (noting that "where a law significantly implicates competing constitutionally protected interests in complex ways," the Court has "balanced interests" in a manner that asks "whether the statute burdens any one such interest in a manner out of proportion to the statute's salutary effects upon the others").

221. Carmen Maye, Public-College Student-Athletes and Game-Time Anthem Protests: Is There a Need for a Constitutional-Analytical Audible?, 24 COMM. L. \& POL'Y 55, 89 (2019).
} 
is permissible - whether, in other words, the regulation is proportionate to the government's regulatory objective-depends in no small part on whether (and the extent to which) core First Amendment values are harmed.

So how did Breyer apply his proportionality approach in Brunetti? First, and importantly, he did not use proportionality when addressing the statutory bar on registering immoral marks. That is because Breyer expressly agreed with the majority that this provision violated the First Amendment. ${ }^{222}$ The majority, it will be recalled, concluded the ban on immoral marks (as well as scandalous ones) was unconstitutional because it allowed the PTO to engage in viewpoint discrimination. ${ }^{223}$

A likely implication of Breyer's agreement with the majority that the immoral marks clause was doomed due to its viewpoint-based nature is this: If there actually is a traditional and categorical doctrine to which Breyer firmly subscribes, it is the one against viewpoint discrimination. This conclusion is buttressed by the fact that in Matal v. Tam, where all of the justices (Breyer included) agreed that the disparagement clause also was impermissibly viewpoint-based, ${ }^{224}$ Breyer did not write separately either to laud the advantages of proportionality or to denigrate the Court's typical categorical approach to analyzing free speech issues. Instead, he simply joined an opinion authored by Justice Alito that concluded "the disparagement clause discriminates on the bases of "viewpoint."'225 In brief, in both Brunetti and Tam, Breyer declined to apply proportionality when he deemed bars on marks - immoral ones in Brunetti, disparaging ones in Tam - to facilitate viewpoint discrimination.

Further supporting the idea that Breyer is keen to adhering to the doctrine against viewpoint-based discrimination is his dissent in National Institute of Family \& Life Advocates v. Becerra. ${ }^{226}$ There, in criticizing the majority for applying heightened scrutiny because it deemed the law was content-based, ${ }^{227}$ Breyer opined that "the majority says nothing about limiting its language to the kind of instance where the Court has traditionally found the First Amendment wary of content-based laws, namely, in cases of viewpoint discrimination." $228 \mathrm{He}$ added in Becerra, when referring to laws affecting speech about abortion, that "we can do our best to interpret American constitutional law so that it applies fairly within a Nation whose citizens

222. Iancu v. Brunetti, 139 S. Ct. 2294, 2308 (2019) (Breyer, J., concurring in part and dissenting in part).

223. Id. at 2299 (majority opinion).

224. Id. at 2297 (noting that while the Court in Tam "split between two non-majority opinions, all Members of the Court agreed that the provision violated the First Amendment because it discriminated on the basis of viewpoint").

225. Matal v. Tam, 137 S. Ct. 1744, 1763 (2017); see also id. at 1751 (noting that Breyer joined in all parts of Justice Alito's opinion).

226. Nat'l Inst. of Family \& Life Advocates v. Becerra, 138 S. Ct. 2361, 2379 (Breyer, J., dissenting).

227. See id. at 2380 ("Before turning to the specific law before us, I focus upon the general interpretation of the First Amendment that the majority says it applies. It applies heightened scrutiny to the Act because the Act, in its view, is 'content based."').

228. Id. at 2381 . 
strongly hold these different points of view."229 Viewed collectively, these two observations in Becerra, along with his assertion there that "the need for evenhandedness" is "particularly weighty" on topics about which "Americans hold strong, and differing, views," 230 clearly suggest that Justice Breyer agrees with the general principle that laws that discriminate unfairly based on viewpoint are impermissible.

Additionally and more recently, Breyer in 2019 joined Justice Sonia Sotomayor's dissent in Manhattan Community Access Corp. v. Halleck. ${ }^{231}$ Sotomayor wrote that regardless of the nature of the forum involved in a First Amendment speech case, "the important point... is that viewpoint discrimination is impermissible in them all."232 Thus, when the four cases are interpreted in the aggregate, Brunetti, Tam, Becerra, and Halleck indicate that Breyer concurs with the traditional doctrine that viewpoint discrimination generally is verboten in First Amendment jurisprudence.

Although Breyer forwent proportionality when considering the bar on immoral marks, he embraced it when analyzing the proscription against scandalous ones. In doing so, he initially concluded, as noted above, ${ }^{233}$ that the statutory term "scandalous" narrowly referred "only to certain highly 'vulgar' or 'obscene' modes of expression." 234 With the statute thus tautly construed, Breyer then applied proportionality, asking whether barring registration of scandalous marks worked harm to First Amendment speech interests that was disproportionate to the government's interests in regulating them. ${ }^{235}$

Initially considering the harm-to-speech-interests facet, Breyer concluded "[n]ot much" harm arose, especially given that scandalous marks can still be used even after the PTO denies registration. ${ }^{236}$ Additionally, because speech serves a very specific function in trademark law-helping consumers identify the origin of goods and services $^{237}$ — and because the government heavily regulates other types of marks that obstruct or frustrate this interest, ${ }^{238}$ individuals seeking registration should know

229. Id. at 2388 .

230. Id.

231. Manhattan Cmty. Access Corp. v. Halleck, 139 S. Ct. 1921, 1934 (2019) (Sotomayor, J., dissenting).

232. Id. at 1936 .

233. See Iancu v. Brunetti, 139 S. Ct. 2294, 2304-07 (2019) (Breyer, J., concurring in part and dissenting in part); see also supra notes 174-176 and accompanying text (describing how Breyer narrowly interpreted the meaning of "scandalous").

234. Brunetti, 139 S. Ct. at 2304 (2019) (Breyer, J., concurring in part and dissenting in part).

235. See id. at 2306 ("I believe we should focus on the interests the First Amendment protects and ask a more basic proportionality question: Does 'the regulation at issue wor[k] harm to First Amendment interests that is disproportionate in light of the relevant regulatory objectives"'? (quoting Reed v. Town of Gilbert, 135 S. Ct. 2218, 2235-36 (2015) (Breyer, J., concurring))).

236. Id. ("The statute leaves businesses free to use highly vulgar or obscene words on their products, and even to use such words directly next to other registered marks. Indeed, a business owner might even use a vulgar word as a trademark, provided that he or she is willing to forgo the benefits of registration."). 237. Id.

238. See id. ("As I have noted, that mission, by its very nature, requires the Government to impose limitations on speech. . . . Trademark law therefore forbids the registration of certain types of words-for example, those that will likely 'cause confusion,' or those that are 'merely descriptive."' (citation omitted) (quoting 15 U.S.C. $\S \S 1052$ (d)-(e) (2019))). 
they cannot register any mark they desire. ${ }^{239}$ Put differently, core First Amendment values for Justice Breyer, such as discovering truth in the marketplace of ideas ${ }^{240}$ or protecting political speech that facilitates democratic self-governance, ${ }^{241}$ are not at stake when it comes to barring marks in trademark law that are scandalous due to their mode of expression.

Turning to the other part of the proportionality equation - the government's interests and objectives in regulating speech-Breyer identified three key reasons justifying denial of registration to scandalous marks: (1) not associating the government with such marks or lending the government's power and imprimatur to promoting them, ${ }^{242}(2)$ the negative effects such marks have on consumers, including their strong emotional, attentional, and memory-grabbing power that threatens not only to "distract consumers and disrupt commerce," but also to spark verbal and physical altercations with offended individuals; $;{ }^{243}$ and (3) reducing the likelihood, through non-registration, that children will be exposed to them in public places. ${ }^{244}$ In brief, denial of registration, although not preventing the use of such marks, may "disincentivize" their use because the mark holders are denied "the benefit[s] of trademark registration." 245 This disincentive to use a mark, in turn, reduces the likelihood of the occurrence of the second and third negative effects above.

Balancing these interests, Breyer concluded that "not very much" harm was worked to First Amendment free speech interests, while a narrowed definition of "scandalous," focusing only on the mode of expression, was "a reasonable wayperhaps the only way - to further legitimate government interests." 246 In other words, the harm caused to First Amendment interests was not disproportionate to the competing interests in barring registration, thus allowing Breyer to uphold the "scandalous" provision as narrowly interpreted. ${ }^{247}$ In summary, Brunetti handed

239. See id. (reasoning that "an applicant who seeks to register a mark should not expect complete freedom to say what she wishes, but should instead expect linguistic regulation").

240. See Nat'l Inst. of Family \& Life Advocates v. Becerra, 138 S. Ct. 2361, 2382-83 (2018) (Breyer, J., dissenting) (stating that he values "widely accepted First Amendment goals," including protecting speech in the marketplace of ideas to facilitate the discovery of the truth, in appropriate cases).

241. As Justice Breyer has written, political speech "lies at the heart of the First Amendment." Nixon v. Shrink Mo. Gov't PAC, 528 U.S. 377, 400 (2000) (Breyer, J., concurring). See Cass R. Sunstein, Constitutional Caution, 1996 U. CHI. Legal F. 361, 373 (1996) ("The heart of the First Amendment lies in democratic self-governance, and when the government regulates political speech, there is special basis for suspicion." (citation omitted)).

242. Brunetti, 139 S. Ct. at 2307 (Breyer, J., concurring in part and dissenting in part) (noting that "when the Government registers a mark, it is necessarily 'involv[ed] in promoting' that mark," and adding that "[ $t]$ he Government has at least a reasonable interest in ensuring that it is not involved in promoting highly vulgar or obscene speech, and that it will not be associated with such speech").

243. Id.

244. Id. ("[S] ome consumers ... believe that such words should not be displayed in public spaces ... where children are likely to be present. They may believe that trademark registration of such words could make it more likely that children will be exposed to public displays involving such words. To that end, the Government may have an interest in protecting the sensibilities of children by barring the registration of such words.").

245. Id.

246. Id.

247. Id. at 2308 . 
Breyer another opportunity to: (1) attack the Court's traditional approach to analyzing free speech cases; (2) explicate his proportionality methodology; and (3) illustrate how proportionality applies to a specific set of facts.

\section{B. Justice Sotomayor On SCRUtiny in An OfFensive-Mode-OF- EXPRESSION ANALYSIS IN TRADEMARK LAW}

Under the Court's traditional approach to analyzing First Amendment speech cases, content-based laws generally are subject to review under the stringent strict scrutiny standard. ${ }^{248}$ In Brown v. Entertainment Merchants Ass' $n$, the Court held that a statute survives strict scrutiny only if "it is justified by a compelling government interest and is narrowly drawn to serve that interest." 249 This test involves two prongs: (1) initially proving a compelling interest; and (2) then demonstrating that the means serving it are sufficiently narrowly tailored. ${ }^{250}$ In short, "even if a law advances a compelling government interest, it will fail strict scrutiny and be held unconstitutional if there is any other way to advance the governmental interest that would restrict less speech."251 Laws rarely survive strict scrutiny review. ${ }^{252}$

The Court's 2015 opinion in Reed v. Town of Gilbert, which struck down a sign ordinance for failing this test, ${ }^{253}$ suggested to some scholars "that if a regulation distinguishes speech according to content on its face, strict scrutiny review applies 'regardless of the government's benign motive, content-neutral justification, or lack of 'animus toward the ideas contained' in the regulated speech."'254 As Professors Dan Kozlowski and Derigan Silver explain, Justice Clarence Thomas's opinion for the Court in Reed "did not make a distinction between laws that target different categories of speech. Justice Thomas wrote in broad strokes, as if all content-based laws, even those that target less protected areas of speech such as commercial speech, should be subjected to strict scrutiny." 255 Others have claimed that Reed "dramatically altered the distinction between content-neutral and content-based

248. See Lakier, supra note 195, at 233; Jason M. Shepard, The First Amendment and Mandatory Condom Laws: Rethinking the "Porn Exception" in Strict Scrutiny, Content Neutrality and Secondary Effects Analysis, 19 NEV. L.J. 86, 108 (2018).

249. Brown v. Entm't Merch. Ass'n, 564 U.S. 786, 799 (2011) (emphasis added).

250. See generally R. George Wright, Electoral Lies and the Broader Problems of Strict Scrutiny, 64 FLA. L. REV. 759, 777 (2012) (identifying strict scrutiny as having "two prongs" and specifying the first prong as requiring a "compelling government interest" and the second prong as requiring "sufficiently narrow tailoring").

251. Kozlowski \& Silver, supra note 189, at 194-95.

252. See Williams-Yulee v. Fla. Bar, 135 S. Ct. 1656, 1666 (2015) (calling the case before it "one of the rare cases in which a speech restriction withstands strict scrutiny").

253. Reed v. Town of Gilbert, 135 U.S. 2218, 2224 (2015) (noting that the sign ordinance identified "various categories of signs based on the type of information they convey, then subject[ed] each category to different restrictions," and concluding that "these provisions are content-based regulations of speech that cannot survive strict scrutiny").

254. Leslie Gielow Jacobs, Making Sense of Secondary Effects Analysis After Reed v. Town of Gilbert, 57 Santa Clara L. Rev. 385, 388 (2017) (quoting Reed, 135 S. Ct. at 2228).

255. Kozlowski \& Silver, supra note 189 , at 192. 
laws," 256 partly because Justice Thomas wrote that "an innocuous justification cannot transform a facially content-based law into one that is content neutral" 257 and "strict scrutiny applies either when a law is content based on its face or when the purpose and justification for the law are content based." 258

Justice Sotomayor's opinion in Brunetti is highly significant because while she concluded that the statute targeting scandalous marks - as she narrowly interpreted $\mathrm{it}^{259}$ — was content-based, ${ }^{260}$ she also found that it was viewpoint-neutral and not subject to strict scrutiny. ${ }^{261}$ For Sotomayor, context was key in making the determination that viewpoint-neutral forms of content discrimination are not always subject to strict scrutiny. The crucial context in Brunetti was that of "discretionary governmental program or limited forum typified by the trademark-registration system." 262 The federal trademark registration program is discretionary, Sotomayor explained, because Congress had no obligation to create it. ${ }^{263}$ In turn, she found "no evidence that speech or commerce would be endangered if the Government were not to provide it at all."264 Alternatively, the federal trademark program can be viewed as a limited public forum, where the government creates a space or adopts an initiative that facilitates "some forms of expression without restricting others." 265 The government typically can restrict speech in limited public forums as long as a regulation is merely reasonable and not viewpoint-based. ${ }^{266}$

In these two contexts-government discretionary programs and limited public forums - Sotomayor determined that the applicable standard of review for testing the validity of a government regulation on speech was neither strict nor intermediate

256. Wegner \& Norchi, supra note 195 , at 600

257. Reed, 135 S. Ct. at 2228.

258. Id.

259. See supra notes 138-139 (addressing Justice Sotomayor's narrow construction of this facet of the statute at issue in Brunetti).

260. See Iancu v. Brunetti, 139 S. Ct. 2294, 2314 (2019) (Sotomayor, J., concurring in part and dissenting in part) ("A restriction on trademarks featuring obscenity, vulgarity, or profanity is similarly viewpoint neutral, though it is naturally content-based.").

261. Sotomayor explained here that:

While the Court has often subjected even viewpoint-neutral content discrimination to strict constitutional scrutiny . . . there are contexts in which it does not. . . When that is the case, the difference between viewpoint-based and viewpoint-neutral content discrimination can be decisive. The federal trademark-registration system is such a context.

Id. at 2315-16 (citations omitted).

262. Id. at 2313.

263. Id. at 2316.

264. Id.

265. Id.

266. Christian Legal Soc'y v. Martinez, 561 U.S. 661, 679 (2010) (noting that "the Court has permitted restrictions on access to a limited public forum ... with this key caveat: Any access barrier must be reasonable and viewpoint neutral"). 
scrutiny, ${ }^{267}$ but rather mere reasonableness. ${ }^{268}$ This approximates the very deferential rational basis standard of review. ${ }^{269}$ That standard typically applies when measuring the validity of economic and social welfare regulations, ${ }^{270}$ while it generally "plays an extremely limited role in free speech cases."271

Applying this reasonableness standard to her narrow construction of the term "scandalous" as only banning the registration of obscene, profane, or vulgar marks, Sotomayor concluded that the clause was constitutional. 272 She believed "the Government has an interest in not promoting certain kinds of speech, whether because such speech could be perceived as suggesting governmental favoritism or

267. See Leslie Kendrick, Nonsense on Sidewalks: Content Discrimination in McCullen v. Coakley, 2014 SUP. CT. REV. 215, 238 (2014) (remarking that intermediate scrutiny "has historically required that the law be 'narrowly tailored to serve a significant governmental interest' and that it leaves open 'ample alternative channels of communication."” (quoting Ward v. Rock Against Racism, 491 U.S. 781, 791 (1989))); R. George Wright, Content-Neutral and Content-Based Regulations of Speech: A Distinction That Is No Longer Worth the Fuss, 67 FLA. L. REV. 2081, 2084 (2015) (noting that "content-neutral regulations commonly receive less exacting, less demanding, mid-level judicial scrutiny" that typically requires the government to demonstrate "a significant or substantial government interest" being served by a "reasonable or proportionate" statute that leaves open ample alternative modes of communication).

268. See Brunetti, 139 S. Ct. at 2317 (Sotomayor, J., concurring in part and dissenting in part) ("Whether he may register his mark can therefore turn on reasonable, viewpoint-neutral content regulations." (emphasis added)).

269. See Brandon L. Garrett, Constitutional Reasonableness, 102 MINN. L. REV. 61, 64 (2017) (noting that "rational basis review ostensibly asks judges to deferentially review reasonable government decisions"); James M. McGoldrick, Jr., The Rational Basis Test and Why It Is So Irrational: An EightyYear Retrospective, 55 SAN DIEGO L. REV. 751, 762 (2018) ("Although the Court is now far more likely to use the rational basis test, there are many examples of the Court referring to a reasonable basis test or using some form of the word reasonable to define the rational basis test.").

270. See Erwin Chemerinsky, The Rational Basis Test Is Constitutional (and Desirable), 14 Geo. J.L. \& PUB. POL'Y 401, 402 (2016) (asserting that "the Court has basically gotten it right about when to apply the rational basis test-using it to analyze government economic regulations and social welfare legislation when there is no discrimination based on a suspect classification or infringement of a fundamental right" (emphasis added)).

271. Ashutosh Bhagwat, The Test That Ate Everything: Intermediate Scrutiny in First Amendment Jurisprudence, 2007 U. ILL. L. REV. 783, 787 (2007). The Court uses a variant of rational basis review when considering the speech rights of public school students when their speech is either sponsored by the school or occurs within the curriculum. Specifically, the Court has held "that educators do not offend the First Amendment by exercising editorial control over the style and content of student speech in schoolsponsored expressive activities so long as their actions are reasonably related to legitimate pedagogical concerns." Hazelwood Sch. Dist. v. Kuhlmeier, 484 U.S. 260, 273 (1988). Erwin Chemerinsky deems this a "classic phrasing of the rational basis review." Erwin Chemerinsky, The Hazelwooding of the First Amendment: The Deference To Authority, 11 FiRST AMEND. L. REV. 291, 294 (2013). Additionally, the Court applies a form of rational basis review in some situations where the government compels the disclosure of factual information related to services provided by individuals, such as attorneys. See Zauderer v. Office of Disciplinary Counsel, 471 U.S. 626, 651 (1985) (holding "that an advertiser's rights are adequately protected as long as disclosure requirements are reasonably related to the State's interest in preventing deception of consumers"); see also Lili Levi, A "Faustian Pact"? Native Advertising and the Future of the Press, 57 ARIZ. L. REV. 647, 681 (2015) (observing that the test in Zauderer is "akin to rational basis review"); but see Nat'1 Inst. of Family \& Life Advocates v. Becerra, 138 S. Ct. 2361, 2372 (2018) (rejecting the application of Zauderer's rational basis test when considering the constitutionality of a compelled-speech obligation imposed on licensed crisis pregnancy centers in California).

272. See Brunetti, 139 S. Ct. at 2317 (Sotomayor, J., concurring in part and dissenting in part) ("Prohibiting the registration of obscene, profane, or vulgar marks qualifies as reasonable, viewpointneutral, content-based regulation.”). 
simply because the Government does not wish to involve itself with that kind of speech."273 In brief, the PTO had a reasonable interest in not indirectly supporting, via the benefits that flow from federal registration, obscene, vulgar, and profane marks. ${ }^{274}$

In summary, Justice Sotomayor created a contextually driven carve-out from the general rule articulated in Reed that strict scrutiny applies to facially content-based laws. In the process of doing so, she also paved a possible path forward for the constitutionality of a redrafted statute barring registration of scandalous marks in accord with her narrow interpretation of that term.

Furthermore, her focus on regulating speech due to an offensive mode of expression, independent of any substantive viewpoints or ideas conveyed, suggests a new line of attack on - or, at least, a potential detour route around-Justice Thomas's logic in Reed regarding when strict scrutiny applies. In Reed, Thomas contended that a law is content-based if it "applies to particular speech because of the topic discussed or the idea or message expressed."275 An offensive-mode-ofexpression regulation, as articulated by Sotomayor, that censors speech regardless of (not "because of," to use Thomas's term above) the topics, ideas, and messages discussed, arguably evades this definition's reach. ${ }^{276}$ In brief, it is possible that statutes targeting how something is said, and not the underlying content, can avoid Thomas's articulation of when a law is content-based. Perhaps, then, Justice Sotomayor did not need to so readily concede that the "scandalous" clause, as she interpreted it, was "naturally content-based."277

On the other hand, Thomas also wrote in Reed that a law is content-based if it targets "speech based on its communicative content."278 Even an offensive-modeof-expression regulation that applies evenhandedly to all topics, ideas, and messages seemingly fits this definition. This is because, at bottom, the regulation exists because the content that is communicated - even if it is just a single word such as "fuck" or "shit" - causes those who hear it to take offense.

The larger, normative question thus raised by an offensive-mode-of-expression carve-out in Sotomayor's Brunetti opinion is this: If an offensive-mode-ofexpression applies evenhandedly to all topics, all subjects, all ideas, and all viewpoints on those topics, subjects, and ideas, then should it presumptively be subjected to strict scrutiny instead of the usual intermediate scrutiny test that applies to content-neutral laws? ${ }^{279}$ Put differently, does a law penalizing only what the Court in Cohen v. California called the "emotive function" 280 of speech, instead of the

273. Id.

274. See id. ("The Government has a reasonable interest in refraining from lending its ancillary support to marks that are obscene, vulgar, or profane.").

275. Reed v. Town of Gilbert, 135 S. Ct. 2218, 2227 (2015).

276. See Brunetti, 139 S. Ct. at 2310 (Sotomayor, J., concurring in part and dissenting in part) (explaining that, under her interpretation of it, "the 'scandalous' clause covers marks that are offensive because of the mode of expression, apart from any particular message or idea").

277. Id. at 2314.

278. Reed, 135 S. Ct. at 2226.

279. See supra note 267 and accompanying text (addressing the intermediate scrutiny test).

280. Cohen v. California, 403 U.S. 15, 26 (1971). 
"cognitive content of individual speech,"281 either presumptively or always demand the application of strict scrutiny just because it affects content? Just how important, in other words, is the emotive function of speech? Is it so important that its jeopardization presumptively demands strict scrutiny, just because content is put into play?

It is crucial to remember here that the Court's famous language regarding the need to protect offensive speech, penned eighteen years after Cohen in Texas v. Johnson, focused on the substantive ideas conveyed, not on the emotive function of speech: "If there is a bedrock principle underlying the First Amendment, it is that the government may not prohibit the expression of an idea simply because society finds the idea itself offensive or disagreeable." 282 What standard of scrutiny, then, should apply to an offensive-mode-of-expression regulation that does not arise in the narrow context of a government discretionary program or a limited public forum, as Sotomayor viewed the context of the government's trademark registration system in Brunetti? 283 Would it be the deferential reasonableness test Sotomayor applied in Brunetti, or would it be some form of heightened scrutiny (be it strict or intermediate scrutiny), or perhaps even the proportionality tack that Breyer used in Brunetti?

After all, the Court in Cohen v. California neither used the term "strict scrutiny" nor articulated and deployed a two-part test such as strict scrutiny. ${ }^{284}$ Yet, the Court in Cohen rejected the notion that states like California could punish the use of words such as "fuck" in public venues like courthouses in order to safeguard "public morality." 285

If a governmental entity today were to adopt an offensive-mode-of-expression regulation for public parks - venues long considered traditional public forums where content-based regulations of speech are subject to strict scrutiny ${ }^{286}$ - that are regularly frequented by large numbers of young children, does Brunetti provide a possible work-around from strict scrutiny? Why couldn't intermediate scrutiny apply? It is a balancing test that typically applies to content-neutral laws. ${ }^{287}$

281. Id.

282. Texas v. Johnson, 491 U.S. 397, 414 (1989) (emphasis added).

283. See supra notes 261-265 (addressing Sotomayor's articulation of this context within Brunetti).

284. Cohen v. California was decided in 1971, prior to the Court's ruling in Police Department of Chicago v. Mosley, which firmly established that "content control" is the essence of forbidden censorship, asserting that "above all else, the First Amendment means that government has no power to restrict expression because of its message, its ideas, its subject matter, or its content." Police Dep't of Chicago v. Mosley, 408 U.S. 92, 95-96 (1972). See also Daniel A. Farber, Playing Favorites? Justice Scalia, Abortion Protests, and Judicial Impartiality, 101 MinN. L. REV. 23, 27 (2016) ("The Court applies a much more stringent test to speech restrictions that relate to content. The content distinction found its first clear expression in Police Department of Chicago v. Mosley.").

285. Cohen v. California, 403 U.S. 15, 22 (1971).

286. See Maye, supra note 221, at 67-68 ("Public streets, parks and the like are traditional public forums; any content-based restriction on speech in traditional public fora must satisfy strict scrutiny."); Laura Rene McNeal, Hush Don't Say a Word: Safeguarding Students' Freedom of Expression in the Trump Era, 35 GA. St. U. L. REV. 251, 280 n.167 (2019) ("It is well established in constitutional jurisprudence that content-based restrictions that occur in traditional public forums are subject to strict scrutiny.").

287. Geoffrey R. Stone, Content Regulation and the First Amendment, 25 WM. \& MARY L. REV. 189, 190 (1983) ("The Supreme Court tests the constitutionality of content-neutral restrictions with an 
Applying it here, courts would consider if there were ample alternative avenues and venues for communicating messages in an emotive fashion, ${ }^{288}$ thereby accommodating the emotive speech interest that is balanced against the government's significant interest in shielding young children from offensive modes of expression. Recall that Justice Breyer was concerned in Brunetti about the display of offensive trademarks in public places where children are present, ${ }^{289}$ and that Justice Sotomayor used children as a benchmark for determining which words are "scandalous" and thus fall within the confines of her offensive-mode-of-expression interpretation of that term. ${ }^{290}$

Ultimately, the justices' disagreements in recent First Amendment cases such as National Institute of Family \& Life Advocates v. Becerra ${ }^{291}$ and Janus v. American Federation of State, County, \& Municipal Employees ${ }^{292}$ over when heightened scrutiny should apply, provide a propitious opening for considering whether strict scrutiny is presumptively mandated when evaluating offensive-mode-of-expression regulations in factual contexts beyond those of Brunetti. The ultimate impact of Brunetti's mode-of-expression logic on Reed's notion of when strict scrutiny applies remains to be seen. At this point, however, it is clear that neither Justice Breyer nor Justice Sotomayor would apply strict scrutiny-the former would use

essentially open-ended form of balancing.”).

288. See Ward v. Rock Against Racism, 491 U.S. 781, 791 (1989) (requiring courts to consider whether content-neutral time, place, and manner regulations "leave open ample alternative channels for communication of the information" (quoting Clark v. Cmty. for Creative Non-Violence, 468 U.S. 288, $293(1984)))$.

289. See supra note 244 and accompanying text.

290. See Iancu v. Brunetti, 139 S. Ct. 2294, 2311 (2019) (Sotomayor, J., concurring in part and dissenting in part) (asserting scandalous vulgarity and profanity should be defined, in part, by whether or not the words in question are "commonly used around children").

291. 138 S. Ct. 2361 (2018). The majority in Becerra applied intermediate scrutiny in holding that the compelled-speech obligation imposed on licensed crisis pregnancy centers was likely unconstitutional. See id. at 2375 ("[T]he licensed notice cannot survive even intermediate scrutiny. California asserts a single interest to justify the licensed notice: providing low-income women with information about statesponsored services. Assuming that this is a substantial state interest, the licensed notice is not sufficiently drawn to achieve it."). In contrast, the dissent applied a deferential standard of reasonableness and, in doing, deemed the provision likely constitutional. See id. at 2381-87 (Breyer, J., dissenting) (observing that "[h]istorically, the Court has been wary of claims that regulation of business activity, particularly health-related activity, violates the Constitution," noting that the government historically has been able to impose "reasonable requirements" and "reasonable conditions" on such activities (including those of medical professionals), and concluding that when it comes to laws requiring medical professionals to disclose factual information, "[t]here is no reason to subject such laws to heightened scrutiny").

292. 138 S. Ct. 2448 (2018). In Janus, the majority spurned the notion that rational basis review applied in analyzing the constitutionality of a state mandate that compelled nonunion members to pay socalled agency or fair share fees to the union that exclusively bargained on their behalf. See id. at 2465 ("This form of minimal scrutiny is foreign to our free-speech jurisprudence, and we reject it here."). Justice Samuel Alito, penning the majority opinion, explained that "[b]ecause the compelled subsidization of private speech seriously impinges on First Amendment rights, it cannot be casually allowed." Id. at 2464. In contrast, the dissent argued that "government entities have substantial latitude to regulate their employees' speech.” Id. at 2487 (Kagan, J., dissenting). Justice Elena Kagan unflinchingly characterized the majority's heightened scrutiny approach as "weaponizing the First Amendment." Id. at 2501. As she bluntly put it, "the majority has chosen the winners by turning the First Amendment into a sword, and using it against workaday economic and regulatory policy." Id. 
proportionality, the latter would use a reasonableness standard - to measure the validity of a future federal statute banning registration by the PTO of marks that are scandalous due solely to their mode of expression.

\section{CONNECTING THE AGENCY DOTS BETWEEN THE PTO AND THE FCC: WILL BRUNETTI EMBOLDEN THE FCC TO REGULATE PROFANITY?}

Just as the PTO is a federal agency engaged in the business of regulating speech when it comes to registering trademarks, ${ }^{293}$ the FCC is a federal agency that makes decisions affecting free expression, but in a different realm. Specifically, Congress has vested the FCC with authority to punish over-the-air broadcasters for transmitting content that is obscene, indecent, or profane. ${ }^{294}$

It is the FCC's regulatory power over the last of those three content categoriesprofane language - where Brunetti may exert some subtle, although clearly not requisite or binding, influence. In particular, both Chief Justice Roberts and Justice Sotomayor contended in Brunetti that the PTO should have authority to deny registration to marks that are profane in their mode of expression and that such power does not violate the First Amendment freedom of speech. ${ }^{295}$

This is significant because the FCC, perhaps fearing the unconstitutionality of its own regulatory power over profane language on the airwaves, has virtually abandoned its enforcement against such expression. ${ }^{296}$ In fact, the FCC in 1976 "recommended that Congress revoke the Commission's authority over profane language due to concerns that it was likely unconstitutional." ${ }^{297}$ Furthermore, since 2007 and as of 2019, the FCC had "not issued a single Notice of Apparent Liability for profanity (in contrast to indecency)." ${ }^{298}$ It is thus safe to conclude that the commission's enforcement of its power over profane language is, at minimum,

293. See Lisa P. Ramsey, Trademark Law Institute for Intellectual Property \& Information Law Symposium: Free Speech Challenges To Trademark Law After Matal v. Tam, 56 Hous. L. Rev. 403, 415 (2018) (observing that the Supreme Court in Matal v. Tam, 137 S. Ct. 1744 (2017), "clarified that use of a trademark is 'speech,' and is not akin to non-expressive conduct or economic activities outside the First Amendment's scope, when the Court held that the disparagement clause was subject to constitutional scrutiny").

294. See 18 U.S.C. $§ 1464$ (2012) ("Whoever utters any obscene, indecent, or profane language by means of radio communication shall be fined under this title or imprisoned not more than two years, or both.").

295. See Iancu v. Brunetti, 139 S. Ct. 2294, 2303 (2019) (Roberts, C.J., concurring in part and dissenting in part) (concluding that "refusing registration to obscene, vulgar, or profane marks does not offend the First Amendment. Whether such marks can be registered does not affect the extent to which their owners may use them in commerce to identify goods. No speech is being restricted; no one is being punished" (emphasis added)); id. at 2313 (Sotomayor, J., concurring in part and dissenting in part) ("Adopting a narrow construction for the word 'scandalous'-interpreting it to regulate only obscenity, vulgarity, and profanity — would save it from unconstitutionality." (emphasis added)).

296. See Lili Levi, "Smut and Nothing But": The FCC, Indecency, and Regulatory Transformations in the Shadows, 65 ADMIN. L. REV. 509, $547 \mathrm{n} .160$ (2013) (observing that by the time the case of FCC $v$. Fox Television Stations, Inc., 567 U.S. 239 (2012), returned to the Supreme Court in 2012, the FCC "appeared to have retired profanity as an independent category for indecency violations").

297. Calvert, Merging, supra note 117, at 182-83.

298. Id. at 153 . 
moribund.

Yet despite these facts, the FCC today continues to state on its website that "[f]ederal law prohibits obscene, indecent and profane content from being broadcast on the radio or TV." 299 In turn, the Commission defines profane expression there as "'grossly offensive' language that is considered a public nuisance." 300 This stands in contrast to its former explication of profane language as only narrowly including religious blasphemy and divine imprecation. ${ }^{301}$

Given the willingness in 2019 of both Republican-nominated Chief Justice John Roberts $^{302}$ and Democrat-nominated Sonia Sotomayor ${ }^{303}$ to allow the PTO to deny registration to trademarks that are profane, might not the FCC view this as suggesting that a carefully drafted definition of profanity that focuses only on the mode of expression might be constitutional as applied to broadcasters? In other words, the opinions in Brunetti of both a perceived conservative and a perceived liberal might embolden the FCC to more aggressively enforce its authority over profane language.

Buttressing this notion is the fact in 2006 the FCC attempted to clarify what it meant by profane language, concluding that "certain vulgar sexual or excretory terms are so grossly offensive to members of the public that they amount to a nuisance and are presumptively profane." "304 The emphasized word "vulgar" is significant because both Roberts and Sotomayor in Brunetti used that exact word when defining the power they believed the PTO should be able to wield against registering offensive marks. ${ }^{305}$ Similarly, Justice Breyer believed the PTO should have authority to deny

299. Consumer Guide: Obscene, Indecent and Profane Broadcasts, FCC, https://perma.cc/28LKEK53 (last visited Oct. 2, 2019).

300. Id.

301. As the FCC explained in 2004:

Broadcasters are on notice that the Commission in the future will not limit its definition of profane speech to only those words and phrases that contain an element of blasphemy or divine imprecation, but, depending on the context, will also consider under the definition of "profanity" the "F-Word" and those words (or variants thereof) that are as highly offensive as the "F-Word," to the extent such language is broadcast between 6 a.m. and 10 p.m. We will analyze other potentially profane words or phrases on a case-by-case basis.

Complaints Against Various Broadcast Licensees Regarding Their Airing of the "Golden Globe Awards" Program, 19 FCC RCD. 4975, 4981 (2004).

302. See Current Members: John G. Roberts, Jr., Chief Justice of the United States, SUPREMECOURT.GOV, https://perma.cc/4N68-2BRW (last visited Sept. 15, 2019) ("President George W. Bush nominated him as Chief Justice of the United States, and he took his seat September 29, 2005.").

303. See Current Members: Sonia Sotomayor, Associate Justice, SuPREMECourT.Gov, https:// perma.cc/4N68-2BRW (last visited Sept. 15, 2019) ("President Barack Obama nominated her as an Associate Justice of the Supreme Court on May 26, 2009, and she assumed this role August 8, 2009.”).

304. Complaints Regarding Various Television Broadcasts Between February 2, 2002 and March 8, 2005, 21 FCC RCD. 2664, 2669 (2016) (emphasis added).

305. See Iancu v. Brunetti, 139 S. Ct. 2294, 2303 (2019) (Roberts, C.J., concurring in part and dissenting in part) (concluding that "refusing registration to obscene, vulgar, or profane marks does not offend the First Amendment. Whether such marks can be registered does not affect the extent to which their owners may use them in commerce to identify goods. No speech is being restricted; no one is being punished" (emphasis added)); id. at 2313 (Sotomayor, J., concurring in part and dissenting in part) ("Adopting a narrow construction for the word 'scandalous'-interpreting it to regulate only obscenity, vulgarity, and profanity—would save it from unconstitutionality." (emphasis added)). 
registration to "highly vulgar"306 marks, while Justice Alito suggested that Congress might adopt "a more carefully focused statute that precludes the registration of marks containing vulgar terms that play no real part in the expression of ideas." ${ }^{307}$ By focusing its definition of profanity on the term "vulgarity," the FCC might have a winning argument with at least some of the justices that its power over profane language is constitutional.

\section{CONCLUSION}

Protecting the right to federally register a trademark for just one single word-a made-up one, no less ${ }^{308}$ - that suggestively sounds like another word, a real one imbued with taboo overtones ${ }^{309}$ that the Court previously had safeguarded back in $1971 .{ }^{310}$ On the surface, and perhaps from a layperson's perspective, that is all that the case of Iancu v. Brunetti was about.

However, the fact that one coined word in Brunetti spawned five different opinions (including three dissenting in part ${ }^{311}$ ) suggests that the case implicated far more than just Erik Brunetti's ability to register "FUCT" as a mark for a line of clothing. ${ }^{312}$ Furthermore, Brunetti proved to be much more than a simple redo of the Court's trademark decision two years prior in Matal v. Tam, ${ }^{313}$ which was rendered without dissent ${ }^{314}$ and in which, as Justice Kagan pointed out in Brunetti, all of the justices agreed that the statutory clause at issue was impermissibly viewpointbased. ${ }^{315}$ Brunetti, in other words, was not Tam II.

From a principles-reaffirming standpoint, Brunetti pounded home the point that viewpoint-based discrimination in speech cases is forbidden when private individuals, as opposed to government entities, are speaking. ${ }^{316}$ Indeed, the principle

306. Id. at 2307 (Breyer, J., concurring in part and dissenting in part).

307. Id. at 2303 (Alito, J., concurring) (emphasis added).

308. Erik Brunetti, in fact, claimed that "FUCT" is supposed to be "pronounced as four letters, one after another" rather than as a single word. Brief for Respondent at 1, Iancu v. Brunetti, 139 S. Ct. 2294 (2019) (No. 18-302). He contended that "[ $\mathrm{t}$ ] $\mathrm{o}$ the extent FUCT has a meaning, it is FRIENDS U CAN'T TRUST." Id. at 2.

309. See Christopher M. Fairman, Institutionalized Word Taboo: The Continuing Saga of FCC Indecency Regulation, 2013 MiCH. ST. L. REV. 567, 616 (noting that "fuck" is one of "many of our taboo words ... [that] involve sex and sex organs" and adding that "[t]he work of psycholinguists show[s] that the taboo status of 'fuck' stems from our deep and dark subconscious feelings about sex").

310. Cohen v. California, 403 U.S. 15 (1971).

311. See Brunetti, 139 S. Ct. at 2303 (Roberts, C.J., concurring in part and dissenting in part); id. at 2304 (Breyer, J., concurring in part and dissenting in part); $i d$. at 2308 (Sotomayor, J., concurring in part and dissenting in part).

312. See id. at 2297 (majority opinion) (noting that Erik Brunetti "founded a clothing line that uses the trademark FUCT").

313. Matal v. Tam, 137 S. Ct. 1744 (2017).

314. See supra notes 6-12 and accompanying text (addressing the Court's ruling in Tam).

315. See Brunetti, 139 S. Ct. at 2297 ("Although split between two non-majority opinions, all Members of the Court agreed that the provision violated the First Amendment because it discriminated on the basis of viewpoint.").

316. See supra Part I.B (addressing how Brunetti reinforces the rule against viewpoint discrimination); see also supra notes 56-62 and accompanying text (addressing how the government speech doctrine allows governmental entities to engage in viewpoint discrimination when they are 
against viewpoint discrimination is what doomed the "immoral" clause for all nine justices. $^{317}$

This reinforcement of a legal doctrine aside, however, Brunetti throws-in the parlance of our times - some serious shade at the long-standing notion that the Court almost unflinchingly, with very few exceptions, protects offensive speech in the face of government censorship. ${ }^{318}$ That is because: (1) three justices (Roberts, Breyer, and Sotomayor) were willing to save the "scandalous" clause by giving it a limiting construction; ${ }^{319}$ (2) one justice (Alito), although unwilling to give "scandalous" a saving construction, proposed a specific way that Congress might redraft the statute to permissibly target certain types of offensive language; ${ }^{320}$ and (3) the six-justice majority stressed that it offered no opinion regarding whether a statutory provision targeting only offensive modes of expression might pass constitutional muster. In the process, one justice also expressed language-driven concerns about the "coarsen[ing] [of] our popular culture" racist speech. ${ }^{322}$ The justices, in a nutshell, are concerned about offensive expression. In short, why offer saving constructions or possible modes of redrafting a statute if there is not some belief among the justices that there are outer limits and boundaries on protecting offensive speech, especially when doing so, in the form of registering a trademark, conveys government-created benefits upon it?

The possibility of an offensive-mode-of-expression carve-out from First Amendment protection, even if only within the highly regulated realm of federal trademark registration where denial does not prohibit use, is intriguing. As argued above, Justice Sotomayor's articulation of such an offensive-mode-of-expression provision goes a long way to clarifying that there is, indeed, a key difference between speech that offends because of a substantive viewpoint or idea and speech that offends merely because of the manner or mode of expressing that viewpoint or idea. $^{323}$ In brief, her opinion illustrates that Justice Alito may have oversimplified matters when he wrote in Tam that "[g]iving offense is a viewpoint." 324

The devil, of course, would be in the definitional details if Congress were to take

considered to be speaking, rather than private individuals).

317. See supra notes 69-70 and accompanying text (noting how the six-justice majority concluded the immoral clause was viewpoint-based, and describing how Chief Justice Roberts and Justices Breyer and Sotomayor also agreed, in their separate opinions, that this clause impermissibly allowed for viewpoint discrimination).

318. See supra Part I.A (addressing the Court's general protection of offensive speech, as well as some exceptions to such protection).

319. See supra Part I.C.3.b, I.C.3.d, and I.C.3.e (addressing, respectively, how Roberts, Sotomayor and Breyer would narrowly interpret the meaning of scandalous to save it from unconstitutionality).

320. See supra Part I.C.3.c (addressing Justice Alito's concurring opinion).

321. Iancu v. Brunetti, 139 S. Ct. 2294, 2303 (2019) (Alito, J., concurring).

322. See id. at 2307 (Breyer, J., concurring in part and dissenting in part) (remarking that "the list of swear words may be evolving yet again, perhaps in the direction of including race-based epithets," and pondering how one "might react if you saw someone wearing a t-shirt or using a product emblazoned with an odious racial epithet"); $i d$. at 2311 n.5 (Sotomayor, J., concurring in part and dissenting in part) (fretting that "the Government will now presumably be compelled to register" what she described as "one particularly egregious racial epithet").

323. See supra Part I.C.3.d.

324. Matal v. Tam, 137 S. Ct. 1744, 1763 (2017). 
up this approach and redraft the scandalous provision accordingly. Terms such as "profanity" and "vulgarity," when used to give meaning to the word "scandalous," would seemingly need to be well defined to avoid a possible, if not inevitable, vagueness challenge. ${ }^{325}$

This Article also emphasized Brunetti's potentially disruptive influence on traditional standards of scrutiny in First Amendment law. Specifically, Justice Breyer continued his nearly indefatigable assault on a categorical approach to scrutiny while he simultaneously propounded proportionality. ${ }^{326}$ This Article suggested, however, that Breyer may actually subscribe to the established doctrine banning viewpoint-based laws targeting private expression. ${ }^{327}$

Furthermore, this Article explained how Justice Sotomayor would not apply strict scrutiny, but instead only a deferential reasonableness test, to analyze the constitutionality of a narrowly drafted offensive-mode-of-expression bar on trademark registration, even though she acknowledged such a provision would be content-based and thus would presumptively be subject to strict scrutiny. ${ }^{328}$ The Article also questioned whether, in fact, such an offensive-mode-of-expression provision actually is content-based, given a definition of that category offered by Justice Thomas in Reed. ${ }^{329}$

Finally, this Article suggested that the FCC may take some comfort in Brunettispecifically, in Chief Justice Roberts's and Justice Sotomayor's opinions- that enforcing its statutory power over profane language on the broadcast airwaves is constitutional. ${ }^{330}$ Although Brunetti is factually confined to federal trademark registration, the reality that it involves another federal agency that operates in another highly-regulated space may embolden the FCC to ratchet up its somnambulant approach to punishing broadcasters for profanity.

Erik Brunetti, in brief, won the right to trademark "FUCT." Yet, in doing so, he may well have nudged the justices closer to creating another carve-out from First Amendment protection for offensive speech, at least within the realm of trademark law and, perhaps, beyond. He also may have coaxed Justice Sotomayor into concluding that such a regulation would not be subject to strict scrutiny, but would face review under a mere reasonableness test. ${ }^{331}$ Indeed, as this Article suggested, an offensive-mode-of-expression arguably might even evade one definition of a content-based law offered by Justice Thomas in Reed $v$. Town of Gilbert. ${ }^{332}$ If that is the case - or even if a possible offensive-mode-of-expression regulation makes the justices reconsider how they define content-based laws or reevaluate Reed's presumption that facially content-based laws must surmount strict scrutiny-then Erik Brunetti will have influenced First Amendment jurisprudence in ways he

325. See supra notes 154-155 and accompanying text (addressing likely problems with vagueness).

326. See supra Part II.A (addressing Breyer's views on scrutiny in Brunetti).

327. See supra Part II.A (including Breyer's views on viewpoint discrimination).

328. See supra Part II.B (addressing Sotomayor's views on scrutiny in Brunetti).

329. See supra notes 275-277 and accompanying text.

330. See supra Part III.

331. See supra note 268 and accompanying text.

332. See supra notes 275-277 and accompanying text. 
probably never envisioned, and his case will have been about far more than just one sophomoric and sexually-suggestive sounding word. 